6-30-2010

\title{
Corporate Social Reporting Initiative - Report to Minister of Finance
}

Poonam Puri

Osgoode Hall Law School of York University, ppuri@osgoode.yorku.ca

Edward J. Waitzer

Osgoode Hall Law School of York University, ewaitzer@osgoode.yorku.ca

Kevin Ranney

Michael Torrance

Follow this and additional works at: http://digitalcommons.osgoode.yorku.ca/reports

\section{Repository Citation}

Puri, Poonam; Waitzer, Edward J.; Ranney, Kevin; and Torrance, Michael, "Corporate Social Reporting Initiative - Report to Minister of Finance" (2010). Commissioned Reports and Studies. Paper 2.

http://digitalcommons.osgoode.yorku.ca/reports/2 


\section{Corporate Social Reporting Initiative}

Report to Minister of finance

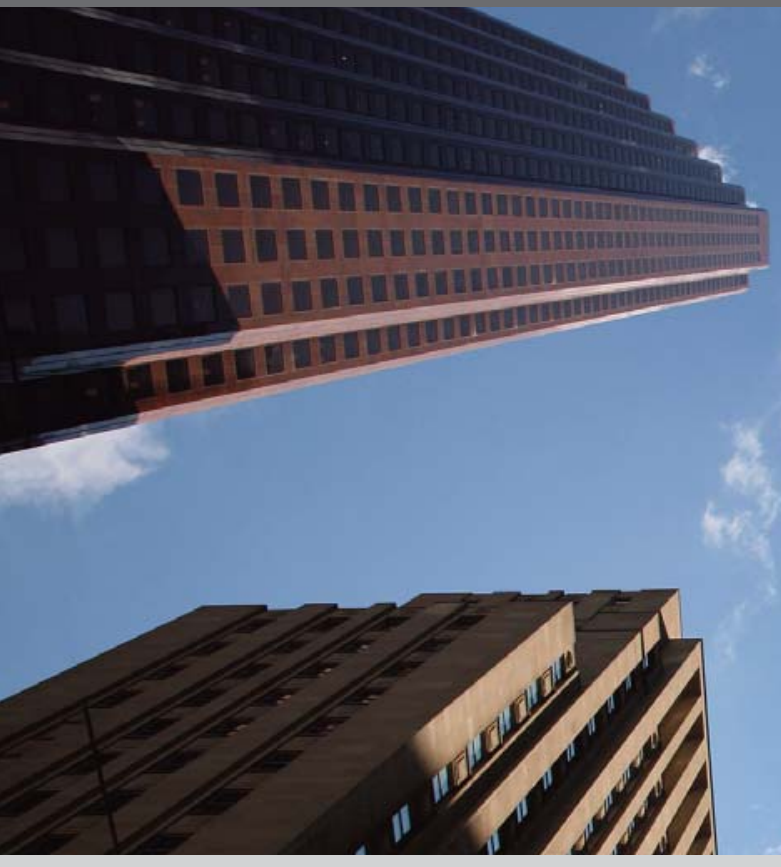

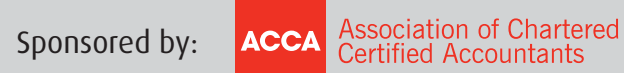

\section{HennickCentre \\ FOR BUSINESS AND LAW}
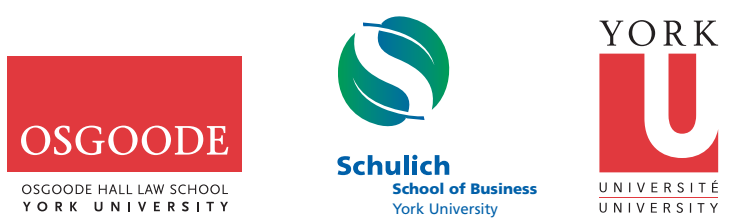


\section{Corporate Social Reporting Initiative Report to Minister of Finance}

The Jay and Barbara Hennick Centre for Business and Law Jantzi-Sustainalytics
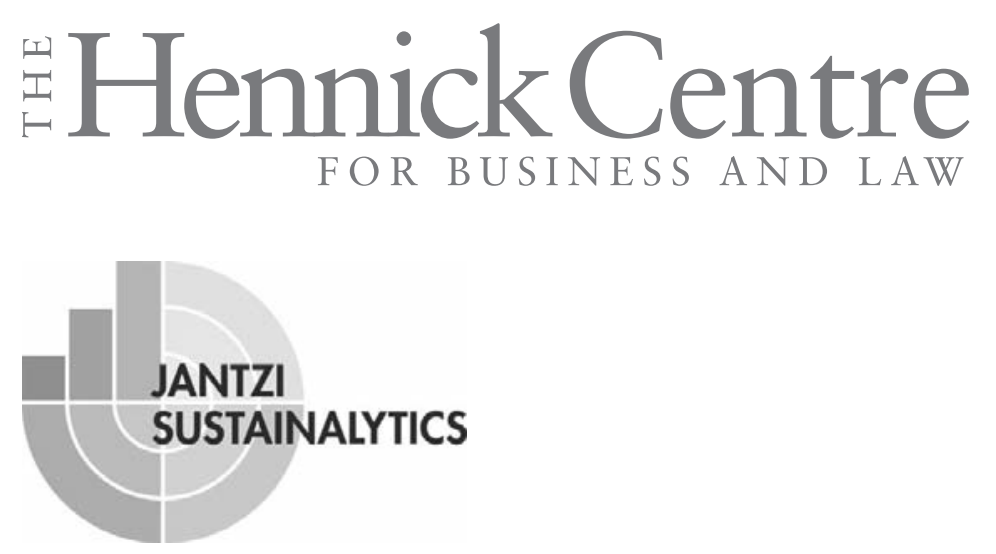


\section{THE HENNICK CENTRE FOR BUSINESS AND LAW}

The Jay and Barbara Hennick Centre for Business and Law focuses on scholarship and practice at the intersection of business, law and public policy. A joint initiative of Osgoode Hall Law School and the Schulich School of Business at York University, the Centre is the first of its kind in Canada.

The Hennick Centre undertakes activities in pursuit of three strategic goals:

1. To create opportunities for increased engagement by current and former students with joint legal and business education, including promoting the growth and differentiation of the JD/MBA program and other business/law scholarship and instruction at York University.

2. To promote interdisciplinary dialogue and collaboration among members of the law, business and other faculties at York University and beyond toward the goal of high-quality and relevant research at the intersection of business, law and public policy.

3. To connect students and faculty with practitioners and policymakers in order to better focus on "big questions" and encourage related academic research, policy reform and innovations in the teaching and practice of business and law.

www.hennickcentre.ca

\section{JANTZI-SUSTAINALYTICS}

Jantzi-Sustainalytics provides environmental, social and governance (ESG) research and analysis as well as responsible investment services to investors around the world. The firm offers global perspectives and solutions that are underpinned by local experience and expertise, serving both values-based and mainstream investors that integrate ESG information and assesments into their investment management.

Headquartered in Amsterdam, the firm operates as Jantzi-Sustainalytics in North America and has regional offices in Toronto, Boston, Frankfurt, and Madrid. The firm has more than 50 staff members with a range of multidisciplinary and industry expertise.

www.sustainalytics.com 


\section{ACCA}

ACCA (the Association of Chartered Certified Accountants) is the global body for professional accountants. ACCA supports its 131,500 members and 362,000 students throughout their careers, providing services through a network of 82 offices and active centres around the world. The growing number of ACCA members and students in Candia is served by an office on Toronto.

ACCA uses its expertise and experience to work with governments, donor agencies and professional bodies, such as the International Federation of Accountants (IFAC), to develop the global accountancy profession and to advance the public interest.

AcCA's reputation is grounded in over 100 years of providing world-class accounting and finance qualifications. It champions opportunity, innovation, diversity, integrity and accountability. By promoting its global standards, and supporting its members wherever they work, ACCA aims to meet the current and future needs of international business.

Since 1991, ACCA has been in the forefront of promoting the need for, and the benefits of, improved reporting of the impact of business activities on sustainable development. Among other activities, ACCA operates its branded Sustainability Reporting Award program in over 20 countries in Europe, Africa, Asia- Pacific and North America. The purpose of these awards is to showcase the efforts of companies which provide outstanding disclosure of their social, environmental and economic performance. The awards also serve as an incentive for other companies to start or improve their disclosure efforts.

ACCA's sponsorship of the Hennick Centre's Corporate Social Reporting initiative is one of the many paths ACCA has taken to advance the discussion, which is taking place internationally, about the improvement and refinement of non-financial reporting requirements for public companies. We believe this report will make an important contribution to that end.

www.canada.accaglobal.com 


\section{TABLE OF CONTENTS}

$\begin{array}{lr}\text { Executive Summary } & 8\end{array}$

1. Background 9

1.1. Mandate 9

1.2. Consultation and Report on Environmental Disclosure 10

1.3. Hennick Centre/Jantzi-Sustainalytics Consultation on Corporate Social Disclosure 10

2. Context for Review of Corporate Social Disclosure 11

2.1. The Impetus for Enhanced Disclosure 11

2.2. Existing Disclosure Obligations 12

2.2.1. Social Disclosure in the MD\&A 12

2.2.2. Social Disclosure in the AIF

3. The Way Forward 15

3.1. Clarifying the Materiality of Social Disclosure in the MD\&A and AIF Forms 17

3.2. Adopting a "Disclose" Regime 19

3.3. Promoting Stakeholder Engagement (to Refine the Scope of and Metrics for Social Disclosure) 20

3.4. Promoting Standardization of Social Performance Indicators 22

3.5. Compliance Monitoring and Promoting Internal Controls 23

$\begin{array}{ll}\text { 4. Conclusion } & 24\end{array}$

5. Summary of Recommendations 22

\section{ADDENDA}

APPENDIX “A" Broten Resolution $\quad 27$

APPENDIX "B" OSC Corporate Sustainability Reporting Initiative 29

APPENDIX "C" Corporate Social Performance: Reporting Roundtable Consultation Paper 39

APPENDIX "D" List of Attendees at December 7th Roundtable Consultation 67

APPENDIX “E" December 7, 2009 Roundtable Consultation Agenda 69

APPENDIX " $F$ " Dissemination Strategy and Comments Received 71 


\section{EXECUTIVE SUMMARY}

In response to a Private Member's Resolution calling upon the Ontario Securities Commission to conduct a consultation on corporate social responsibility and environmental, social and governance reporting standards and to adopt an enhanced standardized reporting framework, the Hennick Centre for Business and Law and Jantzi-Sustainalytics undertook a multistakeholder consultation process in respect of requirements regarding corporate social disclosure standards. This report to the Minister of Finance reflects a synthesis of the views that emerged from that process. The recommendations herein complement those contained in the Commission's report to the Minister of Finance, dated December 18, 2009 (regarding environmental and governance disclosure), as well as those reflected in OSC Staff Notice 51716. They reflect a growing demand for improved social performance disclosure to facilitate better governance and decision-making on the part of issuers, investors and other stakeholders.

The report recommends that OSC staff issue clarifying guidance with respect to existing social disclosure obligations in the MD\&A and AIF forms, calling for issuers to disclose the existence (or absence) of social policies and management systems that are fundamental to their operations. If such policies exist, the disclosure should evaluate their effectiveness.

The OSC is also called upon to take the lead (i) in sponsoring a regular dialogue between issuers, investors, industry associations, regulators and other stakeholders regarding the materiality and modalities of social disclosure and (ii) in encouraging a shift towards more standardized, industry specific metrics and reporting.

This process of engagement, coupled with active monitoring of disclosure trends and periodic review of issuer disclosure practices, should foster an iterative process that will enhance reporting and governance practices over time. 


\section{BACKGROUND}

\subsection{Mandate}

Events of the last several years have demonstrated the need for better information, incentives and institutions to encourage decision-makers to take a broader and longer term view and to identify and confront risks in an integrated manner, before they erupt systemically. Better disclosure is a cornerstone for developing governance models that can anticipate and manage, rather than simply react to, such complexity and risks. Success in addressing challenges as diverse, in today's tightly inter-connected environment, as climate change, fiscal crises (and their social and political implications) or chronic disease will depend on the ability of corporations and capital markets to integrate sustainability considerations into business strategy. This presupposes reporting of "material" risks, goals and performance information for key environmental and social challenges.

In an effort to focus public policy on this challenge, on April 9, 2009 the Honourable Laurel Broten (Member of Provincial Parliament for Etobicoke-Lakeshore) introduced a Private Member's Resolution which was passed unanimously by the Ontario Legislature (the "Broten Resolution"). ${ }^{1}$ The Broten Resolution called upon the Province of Ontario to review its existing corporate disclosure reporting requirements and compliance with those requirements, with particular emphasis on additional financial and non-financial information needed to ensure that Ontario investors have access to all information material to them in making investment decisions.

As part of the review, the Broten Resolution called upon the Ontario Securities Commission (OSC) to conduct a consultation on corporate social responsibility (CSR) and environmental, social and governance (ESG) reporting standards, and to adopt an enhanced standardized reporting framework for both quantitative and qualitative social and environmental information to ensure that corporate disclosures are understandable, comparable and outcome-focused. The Broten Resolution called for a report, including policy recommendations, to be submitted to the Minister of Finance.

Following the approval of the Broten Resolution, the Ministry of Finance and the OSC agreed that the 0SC would focus their review and consultations on disclosure requirements under Ontario securities legislation for reporting issuers (other than investment funds) regarding corporate governance and environmental matters. It was also agreed that the Hennick Centre for Business and Law ("Hennick Centre") would assist the OSC in its mandate and, in cooperation with the OSC, undertake a separate review regarding corporate social disclosure standards. Each of the consultations described below were held under Chatham House rules of non-attribution.

The Hennick Centre's efforts have been undertaken with generous sponsorship from the Association of Chartered Certified Accountants (ACCA). 


\subsection{Consultation and Report on Environmental Disclosure}

The Hennick Centre assisted in facilitating a roundtable discussion convened by the OSC on September 18, 2009. A consultation paper on the topic of environmental and governance disclosure was prepared by the OSC for that session. The results of that consultation, as well as consultations with the 0SC's Continuous Advisory Committee, Securities Advisory Committee, staff of other Canadian Securities Administrators (CSA), the Prospectors and Developers Association of Canada and with other interested individuals and institutions are reflected in the OSC's Report to the Minister of Finance dated December 18, 2009, as well as the publication of OSC Notice $51-717 .{ }^{2}$

\subsection{Hennick Centre/Jantzi-Sustainalytics Consultation on Corporate Social Disclosure}

In addition to assisting 0SC staff in their consultation process, the Hennick Centre and JantziSustainalytics undertook a parallel review and consultation process in respect of corporate social disclosure standards. This process consisted of three components: (i) the preparation of a consultation paper, ${ }^{3}$ (ii) convening a roundtable discussion on December 7, 2009, and (iii) the circulation of the consultation paper through various channels for broader input beyond the roundtable.

The consultation paper reviewed trends underlying the growing demand for social disclosure, disclosure requirements and practices in other jurisdictions, and relevant academic literature. The multi-stakeholder roundtable consultation included representatives from issuer companies (from the mining, banking and energy sectors among others), academia, investor organizations, advocacy groups and government agencies. ${ }^{4}$ Participants at the roundtable engaged in discussion on the following topics: ${ }^{5}$

- Whether corporate social reporting should be the subject of regulation, and if so, the proper scope of such regulation;

- Compliance challenges facing issuers (and their service providers) in providing social disclosure;

- Policies and practices respecting corporate social reporting in other jurisdictions.

Each session was moderated by one of the authors of the consultation paper, who presented context from the paper and introductory questions. These sessions were followed by small group breakout sessions; each group brought forward recommendations on steps that the OSC could take to enhance corporate social reporting.

As noted above, the consultation paper was also circulated for comment to relevant institutional investors, NGOs, industry associations, government agencies, corporations, scholars and advocacy groups. ${ }^{6}$

This report reflects the valuable input obtained from a wide range of concerned individuals and institutions. It advances recommendations for reform which reflect these views and which are intended to ensure that Ontario's regulatory framework remains relevant and responsive to the needs of market participants and serves the public interest.

2 OSC Corporate Sustainability Reporting initiative, attached as Appendix B.

3 Corporate Social Performance Roundtable, attached as Appendix C.

4 A list of attendees is attached as Appendix D.

5 A detailed agenda of the roundtable consultation is attached as Appendix $E$.

6 A summary of the dissemination strategy and list of those who submitted comments is attached as Appendix F. 


\section{CONTEXT FOR REVIEW OF CORPORATE SOCIAL DISCLOSURE}

\subsection{The Impetus for Enhanced Disclosure}

Disclosure requirements are intended to ensure that investors have access to information about issuers relevant to their investment decisions, thereby helping to facilitate allocational efficiency and contributing to confidence in the integrity of capital markets. Complete material disclosure allows investors to have the most accurate and current information on which to base the management of their portfolios.

There is a growing body of research to support the view that the information needed by investors includes information on corporate social performance (e.g., human rights, labour relations, consumer protection, health and safety, aboriginal relations). The overarching conclusions of two reports by the Asset Management Working Group of United Nations Environment Programme Finance Initiative ("UNEP-FI") were that environmental, social and corporate governance issues affect long-term shareholder value, and in some cases those effects may be "profound" ${ }^{7}$ A recognition that relevant social issues and corporate social performance can affect value was shared generally among participants in the consultation process.

Increasingly, investor demand for information is driven by more than a simple "buy/hold/sell" focus and reflects a broader view of longer-term ownership and engagement. ${ }^{8}$ For example, a coalition of global investors from 13 countries, managing over U.S. \$1.2 trillion of assets, recently wrote to 86 major issuers urging them to honour transparency commitments they had made to the U.N. Global Compact (the world's largest voluntary corporate responsibility initiative). ${ }^{9}$ Likewise, in response to engagement with major institutional shareholders, Shell recently announced that $20 \%$ of executive performance-based compensation will be benchmarked to criteria used for the Dow Jones Sustainability Index. ${ }^{10}$

Beyond investor demand there is a broader public interest in corporate social reporting. We no longer think of financial markets as being isolated from issues such as human rights or climate change. North America has fallen behind many European countries (and others, such as South Africa), which require standardized social disclosure for this reason.

The existing securities law regime requires issuers to disclose corporate social information if it is "material". Applying the threshold test of materiality requires issuers to disclose information wherever a "substantial likelihood" exists that the information will (i) be expected to have a significant effect on the market price or value of any of the issuer's securities, ${ }^{11}$ or (ii) be considered important for a "reasonable investor" in deciding how to vote or make an investment decision. ${ }^{12}$ Where there is some degree of doubt as to the materiality of information, the U.S. Supreme Court has indicated that it is appropriate that these doubts be resolved in favour of the interests that securities laws are designed to protect, namely those of investors and the marketplace. ${ }^{13}$ However, despite evidence of materiality of social

7 "The Materiality of Social, Environmental and Corporate Governance Issues to Equity Pricing" (2004), online: UNEP FI - Work Streams, AMWG, http://www.unepfi.org/work_streams/investment/amwg

8 To the extent this is not the case, the regulatory focus is now shifting to ensuring that incentives of fund managers (and their service providers) are better aligned with the interests of beneficial owners.

9 "Investors step up pressure on corporate responsibility reporting" (February 15, 2010), online: United Nations Principles of Responsible Investing, www.unpri.org

10 D. Brooksbank, "Shell freezes exec salaries and includes sustainability performance after shareholder pressure" (February 17, 2010), online: www.responsible-investor.com

11 See, for e.g., Ontario Securities Act, R.S.0. 1990, c.S.5, s. 1(1).

12 These principles emerge from U.S. securities law which is generally applied in Canadian common law, see TSC Industries, Inc. v. Northway, Inc. (1976), 426 U.S. 438 at 448; Basic Inc. v. Levinson (1988), 485 U.S. 224.

13 TSC Industries Inc. v. Northway, Inc., ibid. 
performance, issuers have generally taken a narrow view of materiality as regards social performance disclosure, particularly where the materiality of such information arises over the long-term.

The efficacy of the relatively short-term focus implied (to date) by the "market impact" test is being challenged. "Reasonable investors", as well as public and private sector leaders, are being called on to take a broader view.

The difference between the corporate social disclosure that would be expected under the existing regulatory regime and what is actually disclosed can be referred to as a "disclosure gap". The disclosure gap is being addressed, to some extent, by voluntary initiatives amongst issuers and non-governmental organizations interested in promoting enhanced disclosure on environmental, social and governance issues. A notable example is the Global Reporting Initiative (GRI), which has developed a sustainability reporting framework that encompasses economic, environmental and social performance. Such initiatives are still at a relatively nascent stage. For example, of the over 1,400 companies listed on the Toronto Stock Exchange, only 24 reported on their social and environmental performance using the GRI framework in 2009. ${ }^{14}$

In addressing the disclosure gap in Canada a majority of consultation participants believe that the existing continuous disclosure regime has the potential to result in improved disclosure. The question then becomes whether and, if so, how the OSC should encourage enhanced corporate social disclosure by issuers, in order to meet the demand of market participants for such information and to encourage better governance and risk management.

\title{
2.2 Existing Disclosure Obligations
}

\begin{abstract}
National Instrument 51-102 ("NI 51-102") requires periodic reporting in the form of: (i) financial statements; (ii) Management Discussion and Analysis Form NI 51-102F1 ("MD\&A") ${ }^{15}$ and; (iii) Annual Information Form NI 51-102F2 ("AlF"). ${ }^{16}$ Both the MD\&A and AIF Forms direct reporting issuers to focus their disclosures on items and issues that are "material" and both forms define "material" information as follows: ${ }^{17}$

Would a reasonable investor's decision whether or not to buy, sell or hold securities in your company likely be influenced or changed if the information in question was omitted or misstated? If so, the information is likely material.
\end{abstract}

The definition of "materiality" incorporated into NI 51-102 implies a "reasonable investor" threshold. This is to be distinguished from the "market impact test" applied in the definitions of "material fact" and "material change" as defined in the 0ntario Securities Act, which refer to a fact or change, "...that would reasonably be expected to have a significant effect on the market price or value of the securities...". ${ }^{18}$

NI 51-102 specifically references requirements respecting disclosure of social (and environmental) risks, policies and practices.

14 See Global Reporting Initiative, online: http://www.globalreporting.org/GRIReports/GRIReportsList/. of the companies that produce CSR/sustainability reports in Canada, many use GRI Guidelines to develop their reporting framework even if they do not report in accordance with the Guidelines.

15 See Part 1(e).

16 See Part $1(\mathrm{f})$.

17 See Form NI 51-102FI Part 1(f); and Form NI 51-102F2 Part 1(e).

18 Supra note 11. 


\subsubsection{Social Disclosure in the MD\&A}

The MD\&A is a narrative analysis prepared by management to assist investors in interpreting the information contained in a reporting issuer's financial statements.

Section 1.4 of the MD\&A requires reporting issuers to provide an analysis of the company's operations, including consideration of "known trends, commitments, events, risks or uncertainties that you reasonably believe will materially affect your company's future performance including net sales, total revenue and income or loss before discontinued operations and extraordinary items" and "unusual or infrequent events or transactions."19 Reporting of social issues will often fall within these general provisions. ${ }^{20}$

In addition, section $1.4(\mathrm{~d})$ of the MD\&A requires reporting issuers having significant projects that have not yet generated operating revenue to disclose "any factors that have affected the value of the project(s) such as change in commodity prices, land use or political or environmental issues." 21

In a 1989 Release, the SEC addressed similar disclosure requirements under U.S. securities law by articulating a "double negative" standard. Firstly, in evaluating trends and other factors affecting business, management must consider whether such phenomena are "likely to come to fruition". Even if management cannot make that determination, the SEC Release stated they must then make an objective evaluation of "the consequences of the known trend, demand, commitment, event or uncertainty, on the assumption that it will come to fruition". Only then can management avoid disclosure and only if it determines "that a material effect on financial condition or results of operations is not reasonably likely to occur." ${ }^{22}$

\subsubsection{Social Disclosure in the AIF}

The AIF provides detailed information about a reporting issuer, its operations and prospects, as well as risks and other factors that affect it. The AIF is intended to provide material information about the history, operations, and financial affairs of a reporting issuer business at a point in time, viewed within the context of historical events and possible future developments. ${ }^{23}$

\section{(a) Social Policies}

The AIF expressly requires disclosure of social and environmental policies, as well as environmental and health risk factors and political considerations. In particular, Item 5.1(4) states:

Social or Environmental Policies - If your company has implemented social or environmental policies that are fundamental to your operations, such as policies regarding your company's relationship with the environment or with the communities in which it does business, or human rights policies, describe them and the steps your company has taken to implement them.

In responding to comments on this provision, the CSA has suggested that the caveat of "materiality" still applies. ${ }^{24}$ The CSA has stated that the "topic" of society and environment covered by Item 5.1(4), "...only applies if the issuer has implemented social or environmental policies that are fundamental to the issuer's operations."

19 NI 51-102F1, ss. 1.4(g) and (j).

20 Aaron A. Dhir, "Shadows and Light: Addressing Information Asymmetries Through Enhanced Social Disclosure in Canadian Securities Law" (2009) 47 Canadian Business Law Journal 435.

21 NI 51-102F2, s. 1.4(d), instruction (ii).

22 Securities and Exchange Commission, Release No. 33-6853 (May 18, 1989).

23 NI 51-102F2, Part 1(a). The AIF is not required for venture issuers.

24 Summary of Comments and CSA Responses, (2003) 26 OSCB (Supp-3) at 28. 


\section{(b) Risk Factors}

Item 5.2 of the AIF requires companies to:

Disclose risk factors relating to your company and its business, such as cash flow and liquidity problems, if any, experience of management, the general risks inherent in the business carried on by your company, environmental and health risks, reliance on key personnel, regulatory constraints, economic or political conditions and financial history and any other matter that would be most likely to influence an investor's decision to purchase securities of your company. If there is a risk that security holders of your company may become liable to make an additional contribution beyond the price of the security, disclose that risk.

In complying with Item 5.2, issuers are instructed to disclose risks in order of seriousness, and not to de-emphasize risks by including excessive caveats or conditions.

\section{(c) Legal Proceedings}

Item 12 of the AIF requires a description of any legal proceedings that the company was subject to, or proceedings known to be contemplated against the company. The instructions state that issuers:

...do not need to give information with respect to any proceeding that involves a claim for damages if the amount involved, exclusive of interest and costs, does not exceed ten percent of the current assets of your company. However, if any proceeding presents in large degree the same legal and factual issues as other proceedings pending or known to be contemplated, you must include the amount involved in the other proceedings in computing the percentage.

These instructions deviate from the general threshold of "materiality" to the extent that they suggest a monetary threshold for disclosure regardless of the relevance of the claim for investment decision-making.

\section{(d) Regulator Action}

Item 12.2 of the Alf requires reporting issuers to describe any:

(i) penalties or sanctions imposed against your company by a court relating to securities legislation or by a securities regulatory authority,

(ii) any other penalties or sanctions imposed by a court or regulatory body that would likely be considered important to a reasonable investor in making an investment decision, and

(iii) settlement agreements entered into before a court relating to securities legislation or with a securities regulatory authority.

No instructions as regards quantitative thresholds are provided.

The SEC's recent climate change - related disclosure guidance ${ }^{25}$ offers a number of topics that, it suggests, "are some of the ways climate change may trigger disclosure requirements by 
[the SEC's] rules and regulations", including:

- existing and pending legislation and regulation;

- existing and pending international treaties and accords;

- indirect consequences of regulation and business trends; and

- physical impacts [of climate change].

It also notes that discussion and analysis of known material trends and uncertainties require issuers "to consider all relevant information, even if that information is not required to be disclosed, and, as with other disclosure requirements, they should consider whether they have sufficient disclosure, controls and procedures to process this information" - i.e., a substantial information-gathering and analytical undertaking is required internally in order to determine whether disclosure requirements have been triggered. The same logic applies to corporate social disclosure.

\section{THE WAY FORWARD}

Given the growing recognition that a wide range of risks pose critical issues for corporate performance and sustainability, the level of interconnections among many such risks, and the global impact of those interconnections, it is not surprising that decision-makers (whether corporate managers or institutional investors) are seeking heightened levels of social disclosure. ${ }^{26}$

In addition to the work undertaken by the 0SC, recent policy responses include:27

- a current project of the Canadian Institute of Chartered Accounts ("CICA") on ESG issues in investor decision making, intended to develop a CICA discussion brief that would present and discuss industry specific ESG metrics used by investors and discuss how ESG metrics could be provided to market participants within existing regulatory reporting frameworks;

- the Sustainable Value Creation Initiative in Norway (and now Sweden), which has brought together the largest institutional investors in those markets to circulate an annual questionnaire to public companies seeking specific ESG disclosure, ${ }^{28}$

- the U.S. Environmental Protection Agency's Mandatory Greenhouse Gas Reporting Rule, requiring some 10,000 facilities that are large sources of emissions to report, beginning data collection on January 1, 2010; ${ }^{29}$

- the U.S. National Association of Insurance Commissioners' recently approved mandatory climate risk disclosure for insurers with annual premiums of U.S. \$500 billion or more, beginning in May 2010; ${ }^{30}$ and

- the SEC's recent interpretive release providing guidance to public companies on the SEC's current disclosure requirements concerning matters relating to climate change. (This was produced in response to various calls for disclosure reform, including from a coalition of 20 public pension funds, public officials and environmental groups that petitioned the SEC to clarify the disclosure requirements that apply to climate change. $)^{31}$

26 See for example, Investment \& Pensions Europe, "Pressure Mounts on Corporate Responsibility Reporting" (February 15, 2010), online: www.ipe.com/news/pressure-mounts-on-corporate-responsibility-reporting_34048.php

27 See, "SEC Issues Ground-Breaking Guidance Regarding Corporate Material Climate Change Risks and Opportunities" (January 27, 2010), online: www.ceres.org

28 Online: Sustainable Value Creation, www.svcinitiative.com

29 United States Environmental Protection Agency, "Mandatory Reporting of Greenhouse Gases" (October 30, 2009) Docket No. EPA - HQ - 0AR - 2008 - 0508, 74 FR 56260.

30 National Association of Insurance Commissioners, "Insurance Regulators Adopt Climate Change Risk Disclosure: (March 17, 2009), online: www.naic.org/Releases/2009_docs/climate_change_risk_disclosure_adopted.htm

31 Supra note 25 . 
While the pace of such calls for reform is accelerating, a majority of participants in the consultation process expressed the view that, for now, prescriptive rule-making by the 0SC would be premature. There are costs of over-(or premature) regulation. For example, in rejecting the view that a fact is "material" if an investor "might" find it important, the U.S. Supreme Court in TSC Industries Inc. warned that

"Management's fear of exposing itself to substantial liability may cause it simply to bury the shareholders in an avalanche of trivial information, a result that is hardly conducive to informed decision-making." ${ }^{12}$

It should be noted that the U.S. Supreme Court's decision pre-dated the dawn of the personal computer and the internet. Our "information age" has become characterized by intermediaries who sift through and recombine limitless data to generate valuable information. If anything, this makes it more difficult to anticipate the potential materiality of data. In such an environment, the costs of non-disclosure - to investors and more broadly to stakeholders must also be considered.

Substantive issues relating to the nature, relevance and reliability/assurance of corporate social disclosure are far from settled. These are issues outside the expertise of securities regulators. Therefore, it was felt that the current role of the osC should be to encourage, rather than to prescribe, the development of better disclosure practices within the existing regulatory framework.

Accordingly, it is recommended that the way forward should entail promotion of best practices within the existing regulatory framework, with continued use of the "materiality" criterion, somewhat more broadly framed, as the benchmark for disclosure. Issuers should be determining with their stakeholders what the contours of materiality should include and how to better respond to social reporting requirements. We believe there is strong support for the OSC to provide guidance and otherwise play a leadership role in this process. Such an approach should allow for implementation of the following recommendations quickly and without the need for legislative amendment, or the promulgation of new standards by the CSA. It will also allow for standards to evolve in response to the needs of investors and issuers over time.

This approach will also serve to legitimize and encourage salutary efforts underway by issuers, investors and other internal and external stakeholders ${ }^{33}$ to improve reporting practices. In responding to requests by an institutional investor to detail risks relating to potential First Nations' opposition to the Northern Gateway pipeline project, an Enbridge spokesman recently noted the "long history of constructive engagement" the company has had with the investor and how they were "philosophically aligned". ${ }^{34}$

At some point in the future, it may be that prescriptive norms for disclosure will become appropriate. At this stage, however, leadership and guidance is more appropriate. The OSC is uniquely positioned to play such a role. Doing so will be welcomed by the majority of market participants. With that objective in mind, we are recommending an integrated set of initiatives to be undertaken by the OSC (set out below) which, taken together, should firmly position Ontario at the forefront of corporate social disclosure and reinforce the Province's broader economic policy framework.

32 TSC Industries v. Northway, Inc., supra note 12

33 Internal stakeholders include investors, workers, managers and directors. External stakeholders include communities, suppliers, business partners, customers, financial professionals.

34 David Milstead, "More Carrot Than Stick", The Globe and Mail, (March 20, 2010), online: Globe and Mail http://www.theglobeandmail.com/report-onbusiness/more-carrot-than-stick/article1496341/ <http://www.theglobeandmail.com/report-on-business/more-carrot-than-stick/article1496341/. 


\subsection{Clarifying the Materiality of Social Disclosure in the MD\&A and AIF Forms}

The general consensus of the consultation was that the existing disclosure regime could serve to help close any existing disclosure gap if expectations were to be more clearly communicated and greater compliance is fostered among issuers. To do so effectively necessitates clarification of the concept of "materiality". In particular, the concept should be understood to extend to issues impacting materially on long term value, in order to facilitate a more informed and balanced approach to business and investment decision-making (and public policy).

While the materiality standard implies a nexus between corporate activity and financial performance, the OSC has previously noted that issuers should not lose sight of the "forest for the trees":

...by assessing the materiality of individual facts piecemeal when the broader factual context suggests a risk faced by an issuer. Some facts may be material on their own, while others may only be material in the context of other facts...common sense must prevail; the broader factual context, or total mix, must not be overlooked when the risk facing the company is a current one. ${ }^{35}$

Effective corporate management and best practices at the international level call for a broader view with respect to the materiality of corporate social disclosure. For example, the GRI voluntary reporting framework defines materiality to include all significant economic, environmental, and social impacts that would substantively influence the assessments and decisions of "stakeholders", as opposed to shareholders. ${ }^{36}$ Similarly, the U.K. Companies Act, 2006 requires companies to perform a "business review" that reports on their social and environmental performance, including key performance indicators to the extent necessary to explain the information presented. ${ }^{37}$ The U.N. Principles for Responsible Investment suggest that the concept of "materiality" should include long-term sustainability indicators relating to environmental, social and corporate governance issues. ${ }^{38}$ In light of these trends towards a broader understanding of materiality, it is recommended that the OSC clearly signal a more expansive definition of materiality as it pertains to corporate social disclosure.

Encouraging issuers to take a broader view of their disclosure obligations under the MD\&A and AIF presents the greatest immediate opportunity to encourage enhanced reporting of corporate social information. It is recommended that OSC staff issue guidance, as discussed below, similar to the effort undertaken as Staff Notice 51-716 on "Environmental Reporting" (hereinafter referred to as "51-716").

\section{(a) Clarify Materiality Threshold as Applied to Corporate Social Performance}

51-716 reinforces a broad interpretation of "materiality" in stating that OSC staff are of the view that:

- issuers should consider both quantitative and qualitative factors in determining materiality generally, and particularly for disclosure relating to environmental matters; and

- meaningful discussion of material environmental matters, where applicable, in an issuer's MD\&A and AIF is important to achieve fair representation of the issuer's financial condition in all material respects.

35 YBM Magnex International Inc. (2003), 26 OSCB 5285 at para. 101.

36 Global Reporting Initiative, "Sustainability Reporting Guidelines", online:

http://www.globalreporting.org/ReportingFrameowrk/ReportingFrameworkDownloads/ at 8.

37 United Kingdom Companies Act, 2006, s. 417.

38 See, for example, the work of the United Nations Principles for Responsible Investment (the "PRI"), online: www.unpri.org 
Similar guidance should be given in respect of corporate social disclosure. Such guidance should interplay with an emphasis on the disclosure obligations set out in item 5.1(4) of the AIF. Expectations under that section were discussed in 51-716 in respect of environmental disclosure as follows:

- We are of the view that discussing environmental policies fundamental to their operations, issuers should evaluate and describe the impact or potential impact these policies may have on their operations. This discussion may include a quantification of the costs associated with these environmental policies, where quantitative information is reasonably available and would provide meaningful information to investors. Boilerplate disclosure is insufficient to properly meet these requirements.

The disclosure of environmental risks expected under item 5.2 of the AIF was also discussed in 51-716 as follows:

- The AIF should provide insight into what the issuer believes are the risks relating to the issuer and its business so that investors can assess the effect of these risks on the issuer's operations and/or financial performance.

The same logic pertains to corporate social disclosure (and should be so indicated).

51-716 places particular emphasis on disclosing any risks related to environmental laws:

- We are of the view that if any risks relating to environmental laws are material to an issuer's operations, whether national or international, the issuer should include a detailed discussion of these laws. This discussion should provide meaningful information to investors. For example, it may include whether or not the issuer is in compliance with these laws and any costs of compliance. Boilerplate disclosure is insufficient to properly meet these requirements.

This suggests that legal risks and compliance for issuers in respect of environmental matters are prima focie material, necessitating a discussion of the legal and regulatory context, including the issuer's approach to compliance. In cases of uncertainty, such as where the potential for new legislation or a change in the law exists, management should be evaluating the reasonable likelihood of legal developments, along with the reasonable likelihood of a material effect on the issuer. ${ }^{39}$

A similar approach should be indicated with respect to corporate social disclosure (including but not limited to human rights, labour relations, health and safety, consumer protection, aboriginal relations) in respect of sections 5.1(4) and 5.2 of the AIF.

\section{(b) Clarify the financial threshold for material litigation from AIF item 12.1}

The plain language of Item 12.1 is broad enough to require disclosure of all material litigation affecting corporate social performance. However, the financial threshold in the instructions appears to limit material disclosure to only include litigation for damages greater than $10 \%$ of corporate assets. For the reasons indicated above, clarification should be provided that this threshold need not be seen as a "bright line" test. Litigation relating to social issues (or the risk thereof) may be indicative of material issues regarding an issuer's strategy or management performance capacity in these areas even if the monetary threshold is not crossed. 


\section{(c) Interpret Item 12.2(b) to include disclosure of all regulatory penalties or sanctions that could be material to investors}

Item 12.2(b) requires reporting issuers to disclose:

Any other penalties or sanctions imposed by a court or regulatory body against your company that would likely be considered important to a reasonable investor in making an investment decision..

Fines or sanctions that are material with respect to corporate social performance will often be seen as "important to a reasonable investor", particularly in light of the trend towards a broader view of materiality and focus on long-term sustainable performance.

\section{(d) Explain Complementarity between AIF and Social Reporting}

The SEC's recent interpretive guidance on climate change notes that certain material risks are being disclosed outside corporate filings in, for example, voluntary sustainability reports using the GRI format, and reports to the Carbon Disclosure Project - two stakeholder-led initiatives. Issuers should be reminded that the AIF is complementary to such voluntary disclosure frameworks and need not impose added costs on issuers that already utilize such voluntary reporting frameworks. The MD\&A permits reporting issuers to incorporate information required to be included in the AlF by reference to another document, which must be disclosed on SEDAR. ${ }^{40}$ This permits an issuer that prepares separate social reporting (such as a report made pursuant to the GRI Guidelines) to file such a report and use it to satisfy AIF disclosure requirements.

Recommendation: As it has done with Staff Notice 51-716 on environmental reporting, OSC staff should issue clarifying guidance with respect to existing social disclosure obligations in the MD\&A and AIF forms.

\subsection{Adopting a "Disclose" Regime}

As described above, while Item 5.1(4) of the AlF takes a broad view of the materiality threshold, the CSA has elsewhere indicated that such disclosure remains conditioned by an apparently narrower view of materiality. More importantly, the CSA has indicated that such disclosure (of social and environmental policies) only applies if and to the extent the issuer has, in fact, implemented policies that are fundamental to its operations. The implication is that no disclosure is required if an issuer has not adopted social or environmental policies or if such policies are not "material" (even if they may be fundamental to the issuer's operations).

This view should be corrected. Disclosure should not be avoidable by failure to create and implement policies. Moreover, as is the case with other evolving standards/best practices in respect of which compliance is voluntary, there should be an affirmative "disclosure" regime, even if the disclosure is negative (i.e., the issuer has no policies and faces no material issues).

The "comply or explain" approach to governance-related practices was introduced in 1992 by the Cadbury Report in the U.K. and has been widely adopted (including in National Instrument 58-101, Disclosure of Corporate Governance Practices). The main premise is that raising standards should not be achieved by rigid, uniform regulation but, rather, that issuers should choose the structures that best suit them, subject to mandatory disclosure that requires them to explain their choices. 
More recently, for U.K. public company reports relating to financial years beginning on or after October 1, 2007, business reviews must include information on environmental, employment, social and community issues and the main factors likely to affect the company's future business. There are no prescribed reporting standards for such a business review, and auditor review is limited to determining whether reporting is consistent with the financial statements. The review must include key performance indicators (KPIs) to the extent necessary for an understanding of the development, performance or position of the business. If social/environmental policies have been implemented, the business review must evaluate their effectiveness. Based on its review of 2009 reports, the U.K. Financial Reporting Review Panel has stated that they will challenge boards to justify an absence of KPIs.

Some will recall the guidance issued by securities regulators (including the $\operatorname{CSA}$ ) in the late 1990s concerning Y2K preparedness, which indicated the need for issuers to devote more attention to Y2K risks in their reporting. Some commentators credited this initiative with causing issuers, investors and other stakeholders to pay more attention to such risks.

The existence (and, by implication, the absence) of policies, management systems and tracking of performance outcomes with respect to social issues is fundamental. Requiring disclosure thereof should serve to (i) focus the attention of corporate decision-makers on such issues and (ii) generate a baseline level of disclosure (and relevant metrics) for all issuers, which can inform evolving practices and policy-making.

Recommendation: The osC should indicate (in the clarifying guidance recommended above) its expectation that, in accordance with Item 5.1(4) of the AIF, (i) all issuers disclose the existence (or absence) of social policies and management systems that are fundamental to their operations and that (ii) if such policies exist, the disclosure should evaluate their effectiveness. In due course, such requirements could be adopted more formally by the CSA.

\subsection{Promoting Stakeholder Engagement (to Refine the Scope of and Metrics for Social Disclosure)}

Most consultation participants agreed that:

- there is a clear and growing gap between investor (and other stakeholder) demand on the one hand and the corporate supply of social reporting on the other, ${ }^{41}$ and;

- while corporate commitment to sustainability and reporting quality is increasing, there is much room for improvement in terms of materiality, assurance and comparability in the quality of information provided. Such information needs to be focused, balanced, easily accessible and rooted in a context of stakeholder engagement.

Issuers, stakeholders and financial professionals generally agree on the need to take account of factors that are not routinely disclosed in financial statements in evaluating the performance and resilience of an organization. These include consideration of political and regulatory risks, quality of human resources management, corporate ethics and effective stakeholder relations, as well as the management of other social risks.

The lack of integration of such information into overall corporate reporting can only serve to diminish the awareness and level of engagement of management, investors and other

41 Certified General Accountants Association of Canada, "Measuring Up: A Study on Corporate Sustainability Reporting in Canada" (2005), online: http://www.cga-canada.org/en-ca/ResearchReports/ca_rep_2005-06_sustainability_1.pdf 
stakeholders. Perhaps this is the key lesson that is emerging in respect of social reporting that it is both an outcome and a process for ensuring effective stakeholder engagement/relationships and for demonstrating that management understands and can manage its business effectively over the long term.

A key challenge is how issuers and investors (and other stakeholders) might best engage in an ongoing dialogue designed to elicit what the broad community of "reasonable investors" and "responsible issuers" consider relevant (i.e. material) in the way of disclosure and, over time, develop and encourage standardized best practices and KPIs.

The OSC should play a critical leadership role in this process, without the need for regulatory intervention. The OSC should assume responsibility for convening a forum of issuers and investors on an annual basis to review the "state of the art" on current issues relating to social reporting, both domestically and elsewhere. It should also undertake educational initiatives designed to encourage the development and implementation of best practices and metrics in social reporting. Such initiatives would serve multiple purposes.

First, they would begin to shift the focus on reporting from being not just an outcome but also a process of dialogue/engagement within a corporation and with its external stakeholders. They would also serve as the basis for guidance to the issuer community, simply by reporting on the materials prepared for such a forum and on the outcome of the discussions. Finally, they would tie-in directly to the monitoring and voluntary standardization processes recommended below.

One might ask why the OSC should take a leadership role in such an initiative as there are a number of other groups that could fulfill that task (and that, we suggest, may wish to partner with the OSC). However, leadership participation of OSC staff in educational programs, as well as the broad dissemination of the proposed consultations, will serve to encourage more relevant disclosure, thereby meeting the policy mandate of the OSC. It would also be consistent with the leadership role assumed by securities regulators in other jurisdictions, including the United States, France, Sweden, Denmark and South Africa.

The assumptions of investors, issuers, regulators and other stakeholders regarding the materiality of social issues and social performance to corporate value will continue to develop and evolve for some time. Similarly, corporate disclosure in this area along with the regulatory requirements governing such disclosure will remain in a process of evolution. A process of ongoing engagement and dialogue among investors, issuers, regulators, and other stakeholders should facilitate and accelerate this process. Engagement with sectoral industry associations will be critical to accelerating the development of standardized KPIs, as discussed below.

Moreover, such a dialogue will assist the OSC in getting input from stakeholders (including issuers and investors) on the effectiveness of social reporting. This will inform OSC guidance and monitoring (discussed below) efforts. This iterative process of continuous feedback will serve to enhance both policy and practice over time.

Recommendation: The OSC should take the lead, in cooperation with others, in encouraging a regular dialogue among investors, issuers, industry associations, regulators and other stakeholders regarding the materiality and modalities of social disclosure and publish the results of such dialogue for broader comment and reflection. An iterative process of engagement, monitoring and feedback will enhance both public policy and reporting practice over time. 


\subsection{Promoting Standardization of Social Performance Indicators}

Investors and analysts who evaluate corporate social disclosure are generally interested in being able to compare the performance of companies, typically within sectors or industries as well as in areas of similar exposure to risks and opportunities. It is therefore important that the data reported by companies on social issues and performance be provided in a manner that facilitates such comparison through the use of common indicators and metrics. This applies to reporting on policies, management systems, programs and initiatives, as well as performance outcomes in specific areas.

The standardization of social performance metrics is complex. There remains a lack of consensus among investors, analysts, issuers and other stakeholders as to what indicators should be used. In addition, with respect to performance outcomes, it is in many areas difficult (and potentially misleading) to reduce outcomes to, and assess them in terms of, specific metrics. The emergence and development of frameworks and metrics to report on social performance is very much an evolutionary process, involving input from a variety of stakeholders.

Currently, there are few standardized metrics for measuring and reporting on social performance. One of the primary objectives of the GRI is to provide a framework and a set of indicators for companies to report on. At the present time, the GRI reporting framework offers the most promising prospect for a standardized framework and set of indicators, although it is currently used by relatively few companies. ${ }^{42}$

Other initiatives have led to the emergence of sector- or issue-specific metrics that are becoming prevalent. In the area of occupational health and safety, for example, the metric of reportable injuries per 200,000 hours worked is reported by a growing number of companies, and used by some sustainability analysts to help compare and assess performance in this area. In certain areas of social relations, such as with aboriginal communities, there is a growing consensus among practitioners and within industry circles regarding what constitutes best practice in engagement and consultation, pointing toward standards for evaluating and reporting on policies and management systems in this area. ${ }^{43}$ The German Government recently sponsored the identification of what it views as the three most important sustainable development KPIs for 68 industry sectors over the next five years. ${ }^{44}$

Despite these examples, there still exist relatively few standardized metrics for measuring corporate social performance. While it is beyond the competency of securities regulators to prescribe such metrics, the OSC should take a leadership role in encouraging issuers and industries to develop appropriate standards, benchmarks and metrics. As noted above, the U.K. Companies Act, 2006 uses the language of KPIs and, in doing so, implicitly recognizes the significance of and need for their use to measure and report on social and environmental performance. ${ }^{45}$ The $0 \mathrm{SC}$ should encourage issuers to develop standardized KPIs that provide useful material information to the marketplace.

The analysis by investors and analysts of the potential impact of social factors on value, whether in the short or long term, will require that, over time, reporting in this area move

42 The Initiative for Responsible Investment at Harvard's Kennedy School of Government is soon to publish a discussion paper outlining methodology for identifying industry specific KPIs for mandatory reporting. The draft report is entitled "From Transparency to Performance". See also, International Institute for Sustainable Development, "Creating Indicators of Sustainability" (September 2007), online: www.iisd.org/pdf/2007igsd_creating_indicators.pdf

43 See, for example, Lindsay Galbraith, Ben Bradshaw, and Murray B. Rutherford, "Towards a New Supraregulatory Approach to Environmental Assessment in Northern Canada" (2007) 25 Impact Assessment and Project Appraisal 1, pp.27-41; Dianne M. Lapierre and Ben Bradshaw, "Corporate Rationales for Negotiating Impact and Benefit Agreements" (Paper presented to the Canadian Institute of Mining, Metallurgy and Petroleum Conference, May 4-7, 2008) online: http://www.cim.org/edmonton2008/conference/TechProgMain.cfm)

44 See Sustainable Development Management (SD-M), "SD-KPI Standard 2010-2014, online: www.SD-M.de 
toward standardization. Therefore, while it would be premature to implement regulatory changes that immediately mandate highly prescribed reporting on specific metric of social performance, the $0 \mathrm{SC}$ should support a shift in the direction of more standardized reporting. This should be an objective throughout the engagement and dialogue processes recommended above. Even at this stage, regulatory guidance can and should identify possible metrics that have been identified by numerous investors, analysts and other stakeholders as relevant and useful.

Recommendation: Without being prescriptive, the osC should support a shift in the direction of more standardized metrics and reporting. In the short term, this would include the identification by issuers of KPIs that are most relevant to their operations and the encouragement of sector-specific (and other) initiatives to develop practical and relevant metrics in the clarifying guidance recommended above and in the OSC's review of continuous disclosure.

\subsection{Compliance Monitoring and Promoting Internal Controls}

Monitoring of compliance trends, to identify problem areas and evaluate outcomes, is an essential part of an effective regulatory approach to enhanced disclosure. ${ }^{46}$ Monitoring should be undertaken through compliance reviews similar to those that have been done in respect of executive compensation and retirement benefits, for instance. ${ }^{47}$ The use of "targeted" reviews of disclosure filings and the resolution of deficiencies that surface through such reviews would also be effective to communicate the importance of social disclosure. ${ }^{48}$ Following compliance reviews, the OSC can seek commitments from specific issuers to enhance aspects of their disclosure in future filings or in the restatement and refiling of materials. ${ }^{49}$

Since 2005 the SEC has posted comment letters (and the responses of issuers) on its website. ${ }^{50}$ Adoption of this practice by the 0SC would serve an educative function, both for issuers and other market participants. ${ }^{51}$

A compliance oriented approach to regulation should focus on ways to embed compliance within organizational routines, as opposed to placing an emphasis on uncovering and punishing malfeasance. ${ }^{52}$ Internal compliance capacity should be encouraged by the 0SC. Compliance reviews should include an assessment of internal systems for control and reporting of reporting issuers. By effect of NI 52-109, comparisons can be made between a firm's internal disclosure control and reporting system and its actual disclosure output. ${ }^{53}$ Disclosure controls and processes should be implemented at all levels of the organization's operations, including the board and senior management levels, not just accounting and financial controls. ${ }^{54}$ Reporting issuers should be encouraged to appoint disclosure compliance officers knowledgeable about social and financial risks and indicators. ${ }^{55}$

There was considerable discussion at the consultation as to the merits of intensifying enforcement efforts in respect of corporate social disclosure. Most were of the view that any

46 Christine Parker, "Reducing the Risk of Policy Failure", (2000) OECD Working Papers vol. 8 no. 77 (Paris: OECD Publishing) ["OECD Report"] at p. 49.

47 Mary Condon, Poonam Puri, "The Role of Compliance in Securities Regulatory Enforcement" (2006) in Canada Steps Up, Report of the Task Force to Modernize Securities Legislation in Canada, Volume 6, online: http://www.tfmsl.ca ["Condon \& Puri"] at p. 64.

48 Ibid, at p. 61.

49 Refiling requests can, in themselves, constitute an adverse consequence, in light of the OSC's Refilings and Errors list which posts names of issuers that restate and refile disclosure materials for a period of three years from the date of refiling.

50 Securities and Exchange Commission, "SEC Staff to Begin Publicly Releasing Comment Letters and Responses" (May 9, 2005) online: http://www.sec.gov/news/press/2005-72.htm

51 See Dhir, Supra note 20 at p. 456.

52 Supra note 47 at 12 .

53 Supra note 47, at 66; NI 52-109 requires CEOs and CFOs of reporting issuers to certify that filings do not contain a misrepresentation, and that "reasonable assurance" can be provided in light of "disclosure controls and procedures" and "internal control over financial reporting".

54 Ibid, 69.

55 Supra note 46 , at 38 
such regulatory focus should be preceded by the process of guidance, engagement and monitoring recommended in this report.

Recommendation: The OSC should actively monitor disclosure trends and related internal controls by undertaking periodic reviews, as it has done in respect of other specific disclosure issues and report thereon, with additional guidance as best practices and industry-specific, standardized KPIs evolve. Comment letters in respect of continuous disclosure filings and issuer responses should be posted on the OSC's website.

\section{CONCLUSION}

As with environmental and governance disclosure, the OSC is uniquely positioned to take a leadership role in promoting better corporate social disclosure, as well as the development of best practices over time. In doing so, the 0SC it will be able to leverage the resources and commitment of issuers, investors and other corporate stakeholders to (i) improve governance and disclosure practices and (ii) ensure Ontario's leadership role in this important dimension of public policy.

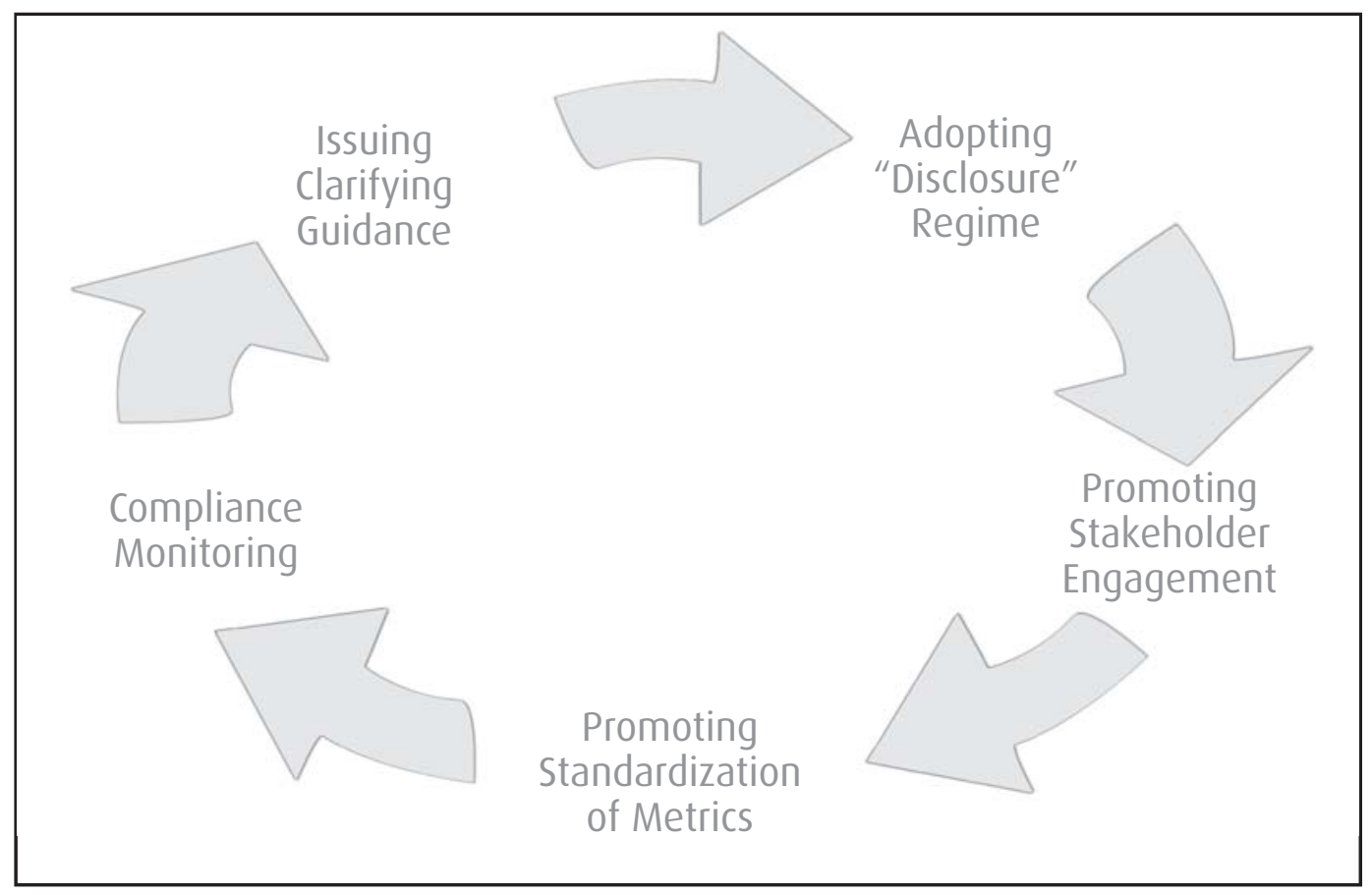

The recommendations in this report, as reflected in the diagram above, are intended to take advantage of the 0SC's unique role to encourage and accelerate the process called for in the Broten Resolution. For reasons described herein, such an initiative would be timely and impactful. 


\section{SUMMARY OF RECOMMENDATIONS}

As it has done with Staff Notice 51-716 on environmental reporting, OSC staff should issue clarifying guidance with respect to existing social disclosure obligations in the MD\&A and AIF forms.

The OSC should indicate (in the clarifying guidance recommended above) its expectation that, in accordance with Item 5.1(4) of the AIF, (i) all issuers disclose the existence (or absence of) social policies and management systems that are fundamental to their operations and that (ii) if such policies exist, the disclosure should evaluate their effectiveness. In due course, such requirements could be adopted more formally by the CSA.

The OSC should take the lead, in cooperation with others, in encouraging a regular dialogue among investors, issuers, industry associations, regulators and other stakeholders regarding the materiality and modalities of social disclosure and publish the results of such dialogue for broader comment and reflection. An iterative process of engagement, monitoring and feedback will enhance both public policy and reporting practice over time.

Without being prescriptive, the 0SC should support a shift in the direction of more standardized metrics and reporting. In the short-term, this would include the identification by issuers of KPIs that are most relevant to their operations and the encouragement of sectorspecific (and other) initiatives to develop practical and relevant metrics in the clarifying guidance recommended above and in the OSc's review of continuous disclosure.

The OSC should actively monitor disclosure trends and related internal controls by undertaking periodic reviews, as it has done in respect of other specific disclosure issues and report thereon, with additional guidance as best practices and industry specific, standardized KPIs evolve. Comment letters in respect of continuous disclosure filings and issuer responses should be posted on the OSC's website. 



\section{APPENDIX A - LAUREL BROTEN RESOLUTION}

On April 9, 2009, the Ontario legislature voted unanimously to support a private member's resolution introduced by Liberal MPP Laurel Broten (Etobicoke-Lakeshore). The non-binding resolution calls on the OSC to conduct a consultation into best practices on corporate social responsibility (CSR) and environmental, social and governance (ESG) reporting standards. The resolution reads:

Be it resolved that, in the opinion of this House, the province of Ontario should undertake a review of Ontario's current corporate disclosure reporting requirements, standards and compliance therewith, with a particular emphasis on additional financial and non-financial information to ensure that Ontario investors have access to all information material to them in making investment decisions.

That, in undertaking such a review, the Ontario Securities Commission (OSC) should undertake a broad consultation with its own advisory bodies including the Continuous Disclosure Committee, concerned stakeholders, appropriate interest groups and individuals and other securities regulators, to establish best practice corporate social responsibility (CSR) and environmental, social and governance (ESG) reporting standards.

That the 0SC seek to develop and adopt an enhanced standardized reporting framework for both quantitative and qualitative social and environmental information to ensure corporate disclosures are understandable, comparable and outcome-focused.

That the 0SC shall report back to the Minister of Finance no later than January 1, 2010, with regard to its findings, together with recommendations for next steps to enhance disclosure. 


\title{
APPENDIX B - OSC CORPORATE SUSTAINABILITY REPORTING INITIATIVE
}

\author{
December 18, 2009
}

\section{INTRODUCTION}

\subsection{OSC's mandate and project scope}

Mandate

On April 9, 2009, the Ontario Legislature approved a broad resolution (the Resolution) introduced by MPP Laurel Broten calling upon the province of Ontario to review Ontario's existing corporate disclosure reporting requirements and compliance with those requirements, with a particular emphasis on additional financial and non-financial information needed to ensure that Ontario investors have access to all information material to them in making investment decisions. As part of the review, the resolution called upon the Ontario Securities Commission (OSC or we) to undertake a broad consultation to establish best practice corporate social responsibility and environmental, social and governance (ESG) reporting standards.

Following the approval of the non-binding resolution, the Ministry of Finance and the osC discussed the appropriate focus and scope of the initiative. The OSC agreed to:

- review existing disclosure requirements under Ontario securities legislation for reporting issuers (other than investment funds) regarding corporate governance and environmental matters

- consult with investors, issuers, advisors and other stakeholders (together referred to as stakeholders) on these matters, and

- make recommendations to the Minister of Finance by January 1, 2010 regarding "next steps" to enhance disclosure of these matters, if determined necessary and appropriate.

Our recommendations must take into account the 0SC's mandate of providing protection to investors from unfair, improper or fraudulent practices and fostering fair and efficient capital markets and confidence in capital markets. In addition, our recommendations should have regard to the following statutory principles:

- The integration of capital markets is supported and promoted by the sound and responsible harmonization and co-ordination of securities regulation regimes.

- Business and regulatory costs and other restrictions on the business and investment activities of market participants should be proportionate to the significance of the regulatory objectives sought to be realized.

In developing the 0SC's mandate, a number of factors were considered, including the areas of concern expressed by investors and other stakeholders, various international developments and the relatively short timeline to complete the initiative. In light of those factors, the Ministry of Finance and the OSC agreed that the OSC should focus on the disclosure of corporate governance and environmental matters at this time. The Hennick Centre for Business and Law at York University (the Hennick Centre) is currently undertaking a review of the existing disclosure requirements under Ontario securities legislation for reporting issuers (other than investment funds) regarding corporate social performance. As part of that 
initiative, the Hennick Centre and Jantzi-Sustainalytics held a roundtable discussion with stakeholders on December 7, 2009. In early 2010, the Hennick Centre will make recommendations to the Minister of Finance regarding "next steps" to enhance corporate social performance disclosure.

The OSC and the Hennick Centre are working cooperatively on both of the OSC and the Hennick Centre initiatives.

\section{Project scope}

The OSC's consultation and review were guided by the following framework questions:

- What information on corporate governance and environmental matters would a reasonable investor need in order to make investment decisions?

- What are the challenges and benefits associated with providing information on corporate governance and environmental matters?

- Are existing disclosure requirements under Ontario securities legislation relating to corporate governance and environmental matters consistent with international requirements and standards?

- Is there additional information regarding corporate governance and environmental matters that is necessary to sustain the reputation of the Ontario capital markets?

- Are our existing continuous disclosure reviews of corporate governance and environmental matters adequate to support compliance with the applicable disclosure requirements?

\subsection{Consultation process}

OSC staff asked stakeholders for feedback on the adequacy of (i) the existing disclosure requirements regarding corporate governance and environmental matters and (ii) issuers' compliance with the requirements.

\section{Roundtable discussion held on September 18, 2009}

On September 18, 2009, the 0SC held a roundtable discussion to which we invited representatives of investors, issuers and professional bodies (such as the Canadian Institute of Chartered Accountants), analysts, legal and accounting advisors and academics. The roundtable discussion was moderated by Edward Waitzer and Poonam Puri, Directors of the Hennick Centre. A consultation paper was distributed to the roundtable participants to seek their input on the initiative and an updated version of that paper is attached to this report as Schedule 1 (the Consultation Paper). A summary of the roundtable discussion is attached to this report as Schedule 2 .

\section{Consultations with advisory committees and other groups}

Between May and November 2009, OSC staff consulted with the OSC's Continuous Disclosure Advisory Committee and Securities Advisory Committee, staff of the other Canadian Securities Adminstrators (CSA) and the Prospectors \& Developers Association of Canada.

\section{Individual consultations}

Between April and December 2009, 0SC staff also consulted with representatives of law firms, accounting firms, Ceres (a U.S.-based network of investors, environmental organizations and other public interest groups working with issuers and investors to address sustainability challenges such as global climate change), Canadian Business for Social Responsibility, Climate 
Change Lawyers Network, Corporate Knights and Shareholder Association for Research and Education (SHARE), as well as advisors to the Canadian Institute of Chartered Accountants.

The feedback OSC staff received from the consultation process has been incorporated into our recommendations to enhance disclosure of corporate governance and environmental matters set out in this report.

\subsection{Review process}

In addition to consulting with stakeholders, OSC staff reviewed the existing disclosure requirements regarding corporate governance and environmental matters and issuers' compliance with the requirements. This review involved an analysis of:

- CSA and OSC staff notices summarizing reviews of compliance with disclosure requirements regarding corporate governance and environmental matters under Ontario securities legislation

- written submissions relating to disclosure requirements on the CSA's corporate governance proposal published for comment on December 19, 2008

- disclosure requirements regarding corporate governance and environmental matters under securities legislation in Australia, Denmark, France, South Africa, the United Kingdom (U.K.) and the United States (U.S.)

- guidelines for disclosure of corporate governance and environmental matters under voluntary reporting frameworks, such as the Global Reporting Initiative Guidelines and the Carbon Disclosure Project (CDP)

- investor initiatives regarding climate change disclosure, such as the September 2007 petition to the U.S. Securities and Exchange Commission (SEC) (as amended)

- international developments in these areas, including initiatives undertaken by the SEC and the European Commission, and

- relevant academic research.

\section{RECOMMENDATIONS TO ENHANCE DISCLOSURE}

\subsection{Objective of recommendations}

The proposed recommendations are designed to result in greater transparency for investors and the Canadian marketplace regarding (i) the nature and adequacy of issuers' corporate governance practices and (ii) the nature and extent of environmental risks and other environmental matters affecting issuers. This should assist investors when making decisions regarding investments and proxy voting. Investors have sought more information on these matters, and based on our consultations, would welcome regulatory action in this area.

The majority of stakeholders consulted as part of this initiative would like to see the 0SC assume a greater role in advancing and promoting corporate governance and environmental disclosure. However, most of them believe that this can best be achieved through providing more guidance to issuers and conducting more continuous disclosure reviews, rather than by expanding existing disclosure requirements. 
Both the majority of stakeholders and the OSC recognize the importance of a harmonized approach to disclosure of corporate governance and environmental matters across Canada. As a result, we have had, and will continue to have, discussions with the CSA regarding the recommendations set out in this report.

As a result, we recommend the following actions be taken to enhance disclosure of corporate governance and environmental matters.

\subsection{Enhancing corporate governance disclosure}

To enhance compliance with the existing corporate governance disclosure requirements set out in National Instrument 58-101 Disclosure of Corporate Governance Practices, we propose the following:

Recommendation \#1 - Conduct a follow-up compliance review on corporate governance disclosure

OSC staff propose to conduct a follow-up compliance review of corporate governance disclosure. The review would build on the results of the CSA 2007 compliance review, outlined in CSA Staff Notice 58-303 Corporate Governance Disclosure Compliance Review.

While the scope and timeline for the review could be finalized at a later date, we recommend that the review involve assessing the corporate governance disclosure in information circulars (or annual information forms or annual management's discussion \& analysis, if applicable) filed in spring 2010 by reporting issuers based in Ontario. Outcomes could include: (i) changes in corporate governance disclosure by the issuers in the review sample, either on a historical or prospective basis, and (ii) the publication of a staff notice, summarizing results of the review and providing guidance on compliance with existing corporate governance disclosure requirements. We propose a completion date for this review by the end of 2010 .

CSA staff would be invited to participate in the compliance review; however, the review could be done on an OSC-only basis if the other CSA jurisdictions choose not to participate.

Recommendation \#2 - Continue educational outreach to issuers

OSC staff should continue to act as instructors with TSX staff at educational workshops on corporate governance disclosure offered by the TSX. The workshops are designed to provide issuers and their advisors with an overview of the corporate governance disclosure requirements and practical guidance on how to apply those requirements. The workshops historically have been offered on an annual basis.

\subsection{Enhancing environmental disclosure}

To enhance compliance with the existing environmental disclosure requirements set out in National Instrument 51-102 Continuous Disclosure Obligations, we propose the following:

\section{Recommendation \#1 - Provide additional guidance for issuers on existing environmental} disclosure requirements

OSC staff propose to issue a notice providing guidance on compliance with existing environmental disclosure requirements, both in general terms and possibly on an industryspecific basis. The staff notice would seek to build on the guidance set out in OSC Staff Notice 51-716 Environmental Reporting and respond to the evolving nature of environmental matters. 
In developing the staff notice, we recommend that an ad hoc advisory committee comprised of experts in this area be established to facilitate developing guidance that is both appropriate and useful for issuers.

While the timeline for the staff notice could be finalized at a later date, we recommend that it be published by fall 2010 so that reporting issuers have sufficient time to consider the guidance when preparing their 2010 annual continuous disclosure documents.

CSA staff would be invited to participate in the development of the staff notice; however, the staff notice could be an OSC-only notice if the other CSA jurisdictions choose not to participate.

Recommendation \#2 - Improve training for 0SC staff on environmental disclosure OSC staff should hold training session(s) for Corporate Finance staff regarding disclosure of environmental matters. The objective would be to identify areas of concern and provide guidance on the types of comments that may be raised during continuous disclosure reviews. These training sessions should be held after the staff guidance is issued.

\subsection{Impact on reporting issuers}

We are not proposing to impose any new disclosure requirements on issuers; however, issuers that are currently not fully complying with existing disclosure requirements may face greater compliance costs than in the past as they work towards improving their disclosure. During our consultations, we were advised that once reporting systems have been established, ongoing compliance costs are often minimal. The stakeholders consulted believe that the benefits to investors from receiving enhanced disclosure will likely exceed any increase in compliance costs for issuers as a result of our recommendations.

\subsection{Commission notice}

We published 0SC Notice 51-717 Corporate Governance and Environmental Disclosure (the Notice) outlining our proposed plans to enhance disclosure of corporate governance and environmental matters on December 18, 2009. The Notice was intended to alert stakeholders to our response to the Resolution and the identified concerns regarding corporate governance and environmental disclosure. In particular, it provides issuers with an opportunity to review and enhance their corporate governance disclosure before being subject to a compliance review.

\section{FEEDBACK AND ANALYSIS}

\subsection{Views expressed during the consultation process}

\section{Materiality of ESG disclosure}

The stakeholders consulted as part of this initiative generally agree that information regarding environmental and corporate governance matters may constitute "material information" which is required to be disclosed in an issuer's continuous disclosure documents filed under securities legislation.

The test for materiality in this context is a "reasonable investor" test. Information is likely 
material if a reasonable investor's decision whether or not to buy, sell or hold securities in an issuer would likely be influenced or changed if the information in question was omitted or misstated. Stakeholders generally believe that the type of information that may affect a reasonable investor's investment decision has shifted in recent years to include a greater scope of corporate governance and environmental matters. This shift is expected to continue as we move towards a carbon-constrained economy.

This view on the materiality of ESG disclosure is confirmed by the paper published by the CFA Institute in 2008, "Environmental, Social and Governance Factors at Listed Companies: A Monual for Investors", which states that:

A growing number of investors (such as those committed to the [Principles for Responsible Investment] and other initiatives) have begun to focus on ESG factors to arrive at a more thorough understanding of the risks and opportunities that face the companies in which they invest. These investors share the view that a prudent investor ought to consider ESG issues in his or her analysis because these factors can have an impact on investment performance.

\section{Concerns regarding deficient disclosure}

During our consultations, stakeholders expressed concerns regarding the adequacy of corporate governance and environmental disclosure. In particular, they noted that:

- the information regarding corporate governance and environmental matters is found in multiple sources: management's discussion \& analysis, annual information forms, information circulars and voluntary reports

- the information is not necessarily complete or reliable, and is often not provided in a form that facilitates comparisons among issuers

- if the information is not included in securities regulatory filings, it is not necessarily provided on a timely basis, and

- in the case of environmental disclosure, the information is often not integrated with financial reporting, nor is it typically audited or verified by an external party.

\section{Adequacy of existing disclosure requirements}

During our consultations, we heard from stakeholders that our existing disclosure requirements regarding corporate governance and environmental matters are generally adequate.

With respect to corporate governance disclosure requirements, stakeholders generally do not support the implementation of the CSA's corporate governance proposal published for comment on December 19, 2008, which included significant changes to the disclosure requirements. Instead, stakeholders favour retaining the existing "comply or explain" disclosure model for TSX-listed issuers and the general disclosure model for venture issuers. While they believe disclosure regarding areas such as risk management and shareholder engagement are important, they expressed the view that now is not an appropriate time to amend the existing requirements to address those areas. Stakeholders generally think that the existing disclosure requirements are adequate and securities regulators should focus on 
improving compliance with those requirements. Stakeholders also generally agree that the existing disclosure requirements are broad enough to capture disclosure of material environmental matters.

\section{Adequacy of compliance with existing disclosure requirements}

The stakeholders consulted as part of this initiative generally believe that the poor compliance with existing disclosure requirements is primarily responsible for inadequate levels of disclosure. This view is supported by the results of compliance reviews conducted by osC and CSA staff and third parties in respect of both corporate governance and environmental disclosure. Those results are discussed in section 3.2 under the heading Concerns regarding deficient disclosure below.

In addition, stakeholders agree that compliance with existing disclosure requirements could be enhanced. They recommend providing issuers with additional guidance on the nature and extent of disclosure required under the existing environmental disclosure requirements, particularly in respect of climate change risk, and reinforcing compliance with corporate governance disclosure requirements through our continuous disclosure review program and educational programs.

\subsection{Research and analysis}

A summary of our research is set out in the Consultation Paper attached to this report as Schedule 1.

\section{Concerns regarding deficient disclosure}

Concerns regarding the adequacy of disclosure of corporate governance and environmental matters in continuous disclosure documents have been noted by OSC and CSA staff, third parties and investors.

\section{a. Results from our continuous disclosure reviews}

We conducted a review of corporate governance disclosure in 2007 and environmental disclosure in 2007- 2008. Overall, we found several areas of deficient disclosure in both reviews.

- Corporate governance disclosure. In 2007, CSA staff reviewed the corporate governance disclosure of 65 TSX-listed issuers and 35 venture issuers. The purpose of the review was to assess compliance with the disclosure requirements in National Instrument 58-101 Disclosure of Corporate Governance Practices, and in particular, to review the substance of the disclosure to assess whether the quality was sufficient to provide a clear and complete account of an issuer's corporate governance practices.

The results of the review are summarized in CSA Staff Notice 58-303 Corporate Governance Disclosure Compliance Review, published on June 29, 2007. Overall, deficiencies in each category of disclosure were identified.

As a result of the review, 27 TSX-listed issuers and nine venture issuers were required to address deficiencies in their next management information circular or annual information form. In addition, two venture issuers were required to refile their management information circulars because they failed to provide any corporate governance disclosure.

10 n November 13, 2009, the CSA announced that they do not intend to implement the corporate governance amendments, as originally published for comment in December 2008. The CSA agreed that now is not an appropriate time to recommend significant changes to the CSA's corporate governance regime. The CSA is considering whether to recommend any limited changes to the corporate governance regime at this time. Any proposed changes would be published for public comment. 
- Environmental disclosure. In 2007, OSC staff reviewed the filings of 35 reporting issuers based in Ontario to assess compliance with the existing disclosure requirements regarding environmental matters. Staff focused on the adequacy of disclosure of matters such as financial liabilities related to the environment, asset retirement obligations, financial and operational effects of environmental protection requirements, environmental policies and environmental risks.

The results of the review are set out in 0SC Staff Notice 51-716 Environmental Reporting, which was published on February 27, 2008. Staff found several areas of deficient disclosure. The information provided by issuers was often boilerplate and did not provide meaningful information to investors. The staff notice provided guidance for issuers to consider when preparing their continuous disclosure documents and was intended to be used by issuers as an educational tool to enhance their disclosure.

\section{b. Results from reviews by third parties}

The results from our continuous disclosure reviews are consistent with the findings of third parties:

- Corporate governance disclosure. The TSX has advised us that it conducts reviews of issuers' corporate governance disclosure annually. In the course of its reviews, when it identifies deficient disclosure, TSX staff engage with the issuers selected for review, with a view to improving their corporate governance disclosure. The results of those reviews are not made public.

- Environmental disclosure. On October 14, 2009, a coalition of Canadian investors and environmental groups (comprised of the British Columbia Investment Management Corporation, Ceres, Climate Action Network Canada and the Climate Change Lawyers Network) called on the OSC to pursue several actions aimed at increasing mandatory disclosure of climate change related risks in securities filings as part of the OSC's initiative on corporate sustainability reporting.

In their submission to the OSC, the signatories included a survey of disclosure in 2008 annual reports by 35 reporting issuers in Ontario in nine industry sectors with market capitalization of at least CDN $\$ 1$ billion. The survey found that the disclosure contained poor or limited descriptions of climate change risks, if the issue was discussed at all. The signatories recommended that the OSC work with the CSA to provide guidance to issuers on how to disclose climate change risks within the context of existing reporting obligations. The signatories also encouraged the OSC to improve corporate governance disclosure of how issuers are addressing their climate change risk at board and management levels.

\section{c. Investor requests for information}

Investors have been requesting information about environmental matters directly from issuers to supplement the information provided in securities regulatory filings.

- Requests for information from issuers. Investors have been requesting information about climate change directly from issuers. The CDP is the largest investor coalition in the world and includes more than 475 signatory investors with assets under management of US\$55 trillion. These investors reflect a wide range of institutions, including banks, fund managers, pension funds, socially responsible investors and insurance companies. They sign an annual request for information which is sent to the chair of the board of each of the world's largest companies by market capitalization. The request for information covers four main areas: management's views on the risks and opportunities related to climate change, greenhouse 
gas emissions accounting, management's strategy to reduce emissions/minimize risk and capitalize on opportunity, and corporate governance with regard to climate change.

- Shareholder proposals. Investors are also making their desire for enhanced environmental disclosure known through shareholder resolutions. According to the Shareholder Resolution Database maintained by SHARE, in the 2009 annual general meeting year, 12 of the 101 shareholder proposals and resolutions filed with Canadian issuers related to environmental matters. They covered topics such as the monitoring of greenhouse gas emissions, participation in the CDP and reporting on the effect of, or exposure to risks relating to, climate change.

\section{Adequacy of existing disclosure requirements}

From our review, Canadian disclosure requirements are comparable to those in other jurisdictions. We reviewed the disclosure requirements in Australia, Denmark, France, South Africa, the U.K. and the U.S. We also reviewed guidelines for disclosure under voluntary reporting frameworks, investor initiatives and relevant academic research.

\section{a. Corporate governance disclosure}

The existing corporate governance disclosure requirements are set out in National Instrument 58-101 Disclosure of Corporate Governance Practices. From our review of the corporate governance disclosure requirements in other jurisdictions, existing Canadian requirements are comparable in many respects to those found in Australia, South Africa and the U.K. These three jurisdictions all apply some form of a "comply or explain" model similar to Canada, and their corporate governance disclosure regimes incorporate recommendations or principles on issues found in the Canadian framework, such as the independence of board directors and the mandate of the board. Some jurisdictions require certain disclosure relating to risk management and shareholder engagement that is not required under the existing Canadian framework. As noted above, the stakeholders consulted as part of this initiative do not believe that now is the appropriate time to amend the existing requirements to address those areas.

The OSC will nonetheless be considering as an on-going policy matter whether limited changes to the existing corporate governance regime are desirable.

\section{b. Environmental disclosure}

The existing environmental disclosure requirements are set out in Form 51-102F1

Management's Discussion \& Analysis and Form 51-102F2 Annual Information Form. The requirements appear to be comparable in some respects to those in other jurisdictions. They are very similar to the requirements under U.S. securities legislation, and are arguably broad enough to capture the same disclosure required under the securities legislation of jurisdictions such as the U.K and Australia.

For the relevant schedules to this appendix and for more information, please see:

http://www.osc.gov.on.ca/en/SecuritiesLaw_sn_20091218_51-717_corp-gov-envirodisclosure.htm<http://www.osc.gov.on.ca/en/SecuritiesLaw_sn_20091218_51-717_corp-g ov-enviro-disclosure.htm>

and

http://www.osc.gov.on.ca/documents/en/Securities-Category5/rule_20091218_51717_mof-rpt.pdf<http://www.osc.gov.on.ca/documents/en/Securities-Category5/rule_20 091218_51-717_mof-rpt.pdf> 


\section{APPENDIX C - CORPORATE SOCIAL PERFORMANCE: REPORTING ROUNDTABLE CONSULTATION PAPER}

Monday, December 7, 2009

Toronto Canada

Presented by:

Hennick Centre for Business and Law at York University

AND

Jantzi-Sustainalytics

\section{BACKGROUND}

\subsection{Purpose of Consultation}

The purpose of this consultation (the "Consultation") is to elicit the views of informed stakeholders in a review of reporting and disclosure requirements under Ontario securities legislation for corporate "social" performance (hereinafter referred to as "corporate social performance"), as that concept is defined in section 1.4 below. In particular, the Consultation's participants are asked to consider whether existing reporting and disclosure requirements on corporate social performance are adequate. If change is advisable, the question becomes what regulatory or other measures merit consideration.

\subsection{Background on the Initiative}

The Consultation is in response to a private member's resolution introduced by the Honorable Laurel Broten (Etobicoke-Lakeshore), ${ }^{1}$ and passed unanimously by the Ontario Legislature (the "Resolution"). ${ }^{2}$ In part, the Resolution calls on the Ontario Securities Commission ("OSC") to conduct a consultation on corporate social responsibility ("CSR") and environmental, social and governance ("ESG") reporting standards, and to adopt an enhanced standardized reporting framework for both quantitative and qualitative social and environmental information to ensure that corporate disclosures are understandable, comparable, and outcome-focused. The Resolution called for a report, including policy recommendations, be submitted to the Minister of Finance.

This will be the second of two consultations emerging from the Resolution. The first session, held on September 18, 2009, was organized by the OSC (with assistance from the Hennick Centre for Business and Law (the "Hennick Centre")) and focused on the areas of environmental and governance disclosure. The December 7, 2009 session will focus on disclosure and reporting with respect to corporate social performance. The Consultation is being organized by the Hennick Centre and Jantzi-Sustainalytics, with sponsorship from the Association of Chartered Certified Accountants. ${ }^{3}$

1 Now Minister of Children and Youth Services and Minister Responsible for Womens' Issues.

2 For the complete text of the Resolution, see Appendix A.

3 The authors of this paper wish to thank Eugene Ellmen of the Social Investment Organization, Paul Costello of ACCA, and Priya Bala Miller of SHARE for their feedback on a draft of this paper. 
Copies of this Consultation Paper will be made available to interested parties who might not be able to participate in the Consultation, for their comment and input into the Consultation process.

\subsection{Mandate and Project Scope}

The Consultation process will involve the following:

- Review of existing disclosure requirements under Ontario securities law for reporting issuers (other than investment funds) regarding corporate social performance;

- A roundtable meeting with stakeholders on the issue of corporate social performance reporting;

- Preparation of a report including recommendations to the Minister of Finance regarding "next steps" to enhance corporate social performance reporting and disclosure.

The Consultation is guided by the following framework questions:

- What information on corporate social performance do investors and other stakeholders want and need?

- What are the challenges and benefits associated with providing information on corporate social performance?

- Are existing disclosure requirements under Ontario securities relating to corporate social performance consistent with international requirements and standards?

- Are the OSC's continuous disclosure reviews of corporate social performance matters adequate to support compliance with the existing disclosure requirements?

- What are the challenges in operationalizing and enforcing disclosure requirements with respect to corporate social performance?

The recommendations that flow from the Consultation will take into account:

- The OSC's mandate of providing protection to investors from unfair, improper or fraudulent practices and fostering fair and efficient capital markets and public confidence in capital markets;

- The ongoing role of the OSC and other securities regulators in defining materiality standards for corporate disclosure and their emerging role in addressing issues of systemic market risk that may be affected by corporate social performance and which could be mitigated by disclosure and reporting on such issues;

- Other legal and policy considerations beyond those of traditional securities regulatory frameworks in respect of which corporate social performance disclosure and reporting may be relevant.

In addition, the recommendations will have regard to the following principles:

- Capital market and regulatory efficacy is supported by the harmonization and coordination of securities regulation regimes;

- Costs and other restrictions imposed on market participants should be proportionate to regulatory objectives sought. 


\section{Questions:}

- Are the framework questions appropriate?

- What additional issues and principles ought to inform the Consultation?

\subsection{The Scope of Corporate Social Performance}

Corporate social performance includes consideration of a broad range of positive and negative effects of corporate behaviour on various stakeholders. Though not exhaustive, the following is a list of stakeholders and issue areas that are encompassed by corporate social performance:

- Community and Society - includes the direct effect of corporate behavior on local communities (often including First Nations communities), corporate engagement and consultation with local communities, contributions to local community development, philanthropy, influence on public policy and political contributions.

- Customers - includes product safety issues, ethical/responsible marketing, advertising practices and fair treatment of customers.

- Employees - includes employee training and development, employment equity and diversity, occupational health and safety, working conditions, labour relations and employee rights (including freedom of association and collective bargaining).

- Supply chain - including labour rights and working conditions in the supply chain.

- Business ethics - including considerations of anti-trust/anti-competitive behavior, bribery and corruption.

- Human Rights - including exposure to and potential complicity in human rights abuses in countries with poor human rights records or conflict zones.

In each of these areas, reporting and disclosure may include information on a company's policies, management and information systems, and initiatives to manage exposure or capitalize on opportunities in these areas. Reporting and disclosure may also include information on any specific concerns, challenges and opportunities that the company has, or may face, and how it manages risk in these areas as well as relevant metrics for measuring performance outcomes.

Questions:

- What other issues should be encompassed by corporate social performance? 


\section{RELEVANCE OF CORPORATE SOCIAL PERFORMANCE REPORTING}

\subsection{Materiality of Corporate Social Performance for Investors}

There is growing recognition in the investment community of the relevance of corporate social performance to the management of investment portfolios. At the same time, long-term investors have become increasingly concerned about systemic risk which, for some, is as or more important than sectoral or firm specific risk assessment. As evidence of these trends, there has been a dramatic increase in demand for such disclosure and corporate social performance related financial research products (e.g., information aggregators, research, rating services, stock exchange indices and related financial instruments). ${ }^{4}$

Many shareholder activists have recognized the relevance of social performance, along with environmental and governance performance. Consequently, improved disclosure on these issues has been a major focus of shareholder engagement initiatives. Such engagement can take a variety of forms, including letter writing, meetings with management, and shareholder resolutions.

Hundreds of shareholder resolutions are filed every year in Canada and the U.S. addressing a variety of ESG issues. According to the Shareholders Association for Research and Education ("SHARE"), between the 2000 and 2009 proxy voting seasons there were 67 resolutions filed in Canada addressing social aspects of corporate performance, with key areas including community engagement, indigenous rights, human rights, employees issues, and customer issues. Among these resolutions, 44 had a component that addressed or requested enhanced reporting on these issues.

There has been a substantial amount of research into the materiality of ESG performance for investors. In 2004, the Asset Management Working Group ("AMWG") of the United Nations Environment Programme ("UNEP") Finance Initiative ("FI") published a report entitled The Materiality of Social, Environmental and Corporate Governance Issues to Equity Pricing, composed of research conducted by nine international brokerage firms. The overarching conclusion of the report was that environmental, social and corporate governance issues affect long-term shareholder value, and in some cases those effects may be "profound". ${ }^{5}$

In 2006, the AMWG published a second report on the issue of materiality. Entitled Show Me The Money: Linking Environmental, Social and Governance Issues to Company Value, the report was a compilation of 12 studies conducted by 10 international brokerage firms on the financial effects of ESG across various sectors. Its key findings were that:

1. ESG issues are material - there is robust evidence that ESG issues affect shareholder value in both the short and long term.

2. The impact of ESG issues on share price can be valued and quantified.

3. Key material ESG issues are becoming apparent, and their importance can vary between sectors.

In October 2007, Mercer and the AMWG published Demystifying Responsible Investment Performance. ${ }^{6}$ The report surveyed academic research into the relationship between ESG issues and financial performance. In November 2009, Mercer released an updated report, Shedding Light on Responsible Investment. ${ }^{7}$ Pooling the results together with the 2007 report,

4 See, for example, H. Shafer, J. Beer, J. Zenker and P. Fernandes, "Who is in Corporate Social Responsibility Rating?", (2006) Bertelsmann Foundation.

5 "The Materiality of Social, Environmental and Corporate Governance Issues to Equity Pricing" (2004), online: UNEP FI: Work Streams, AMWG

http://www.unepfi.org/work_streams/investment/amwg/

6 "Demystifying Responsible Investment Performance" (2007), online: UNEP FI: Workstreams, AMWG

http://www.unepfi.org/publications/investment/index.html

7 Mercer White Paper, "Shedding Light on Responsible Performance" (2009), online at: www.mercer.com/ri 
36 academic studies were surveyed, of which 20 show evidence of a positive relationship between ESG factors and financial performance, while only three show evidence of a negative relationship. The report also focuses on the need to develop comparable and reliable standards in order to "mainstream" the integration of ESG into investment processes.

\section{The Materiality of Corporate Social Performance - Example \#1 - Meridian Gold and the Esquel Project}

Meridian Gold Inc. acquired the Esquel gold property in Argentina in 2002 and developed a plan to construct an open-pit gold mine nine kilometres from Esquel, a city of 30,000 inhabitants. The company failed to implement mechanisms and processes to engage effectively with local communities or to respond to growing concerns over the potential impacts of the mine.

In February 2003, in response to growing opposition to the mine, the mayor authorized a public referendum on the mine's development, which was held the following month. About $75 \%$ of eligible voters participated in the vote, with $81 \%$ voting against the proposed mine. As a result, the company suspended operations.

In the first half of 2003 Meridian's share price fell sharply, driven to a large degree by problems surrounding the Esquel project. In early 2006, as required by accounting regulations, the company wrote down the value of the Esquel property to its fair commercial value without mineral resources, a write-down valued at US $\$ 379$ million. As a result of the write-down the company reported experiencing a net loss US $\$ 346.4$ million for fiscal year 2005 .

See Steven Herz, Antonida Vina and Jonathan Sohn, "Development Without Conflict: The Business Case for Community Consent" (2007) World Resources Institute at 31.

In 2005, former United Nations ("UN") Secretary General Kofi Annan founded the UN Principles for Responsible Investment (the "PRI"). The PRI were developed in response to the work of the AMWG and, more generally, a growing view among investment professionals that ESG issues can affect the performance of investment portfolios, such that appropriate consideration of such issues is necessary to fulfill the fiduciary duty of investment managers. Signatories pledged to incorporate ESG issues into investment analysis and decision making processes, to engage with companies on their ESG performance, and to seek disclosure on ESG issues by the entities in which they invest.

There are currently 633 signatories to the PRI, including asset owners, investment managers and professional service partners, representing over us\$18 trillion of total assets under management. ${ }^{8} 85 \%$ of signatories have policies that make reference to responsible investment or ESG issues and 63\% of asset owners now include responsible investment or ESG elements in contractual relationships with external managers.

Disclosure of ESG performance is a significant focus of the PRI. In its 2009 report on signatories' progress in implementing the principles, the PRI reported that $90 \%$ of signatories had engaged with companies in developed markets regarding their need for standardized ESG reporting. ${ }^{9}$ According to the same report, a number of signatories have cited a lack of disclosure on ESG issues as a key barrier to their implementation of the PRI.

The Australian Council of Super Investors ("ACSI") recently released guidelines entitled "A guide for superannuation trustees on the consideration of environmental, social and governance risks in listed companies" and "A guide for fund managers and consultants on the consideration of environmental, social and governance risks in listed companies". ACSI indicated its belief that good governance requires boards to consider and manage such risks and that consideration of ESG factors in investment decision making is essential. ${ }^{10}$

8 Online: Principles for Responsible Investing <www.unpri.org>.

9 "Report on Progress 2009: A review of signatories' progress and guidance on implementation" (2009), Online: Principles for Responsible Investing www.unpri.org at p. 3.

10 Media Release (October 12, 2009), online: <www.acsi.org.au>. 
Another major initiative that emerged from the growing recognition of the materiality of ESG performance is the Enhanced Analytics Initiative ("EAI"). Founded in 2004, the EAI was an international collaboration of institutional investors that aimed to address the absence of quality research on the impact of extra-financial issues, including ESG issues, on long-term investment value. EAI members committed to allocating at least 5\% of their brokerage commissions to such research. As of mid-2008 EAl members represented total assets under management of about US\$2.4 trillion. ${ }^{11}$

\section{Materiality of Corporate Social Performance - Example \#2 - Talisman Energy and Sudan}

Between October 1998 and March 2003, Talisman Energy Inc. held a 25\% interest in the Greater Nile Oil Project (GNPOC) in Sudan. GNPOC's project included three blocks in the Muglad basin in the Western Upper Nile region of southern Sudan and a 500-kilometre pipeline that runs from the oil fields to Port Sudan on the Red Sea. Production began in 1999.

Northern and southern Sudan had been locked in conflict for decades, and control over areas in the GNPOC concession was divided between the government of Sudan and two rebel movements: the Sudan People's

Liberation Army (SPLA) and the Sudan People's Democratic Force (SPDF).During the civil war, widespread abuses of human rights occurred as both government forces and armed opposition groups indiscriminately and directly targeted civilians and reportedly carried out extrajudicial executions in the context of the civil war. The civil war cost the lives of almost two million people and resulted in the displacement of a further 4.5 million. During the war, there were numerous occasions in which Khartoum used the denial of food and humanitarian aid as a weapon of war.

During its time operating in Sudan, allegations emerged of links between the development of oil by Talisman/GNPOC and the abuse of human rights. It was alleged, for example, that there was evidence that the Government of Sudan, in an effort to secure land for oil development, had forcibly and violently displaced people from areas within and bordering the GNPOC concession since Talisman joined the partnership.While senior management at Talisman Energy emphasized that the company's overall impact on the country was positive and that claims of human rights abuses were unsubstantiated, a broadly-based, international campaign grew in opposition to the company's involvement in Sudan.

The impact of the major controversy over Talisman's operations in Sudan was clear. Prior to the company's investment its shares had sold at a $20 \%$ premium (to net asset value). Subsequent to the emergence of the controversy over its operations it shares were estimated to be trading at a 10 to $20 \%$ discount. Almost immediately after its divestment in March 2003, the company's share price recovered.

Stephen J. Kobrin, "Oil and Politics: Talisman Energy and Sudan", International Law and Politics, Vol. 36:425 2004 .

The foregoing section provides evidence of the materiality of corporate social performance and ESG for investors. As the next section will consider, transparency on corporate social performance may also relate to broader policy interests in effective corporate governance, since it provides a tool for companies to better understand stakeholder concerns, and for stakeholders to better understand corporate practices, thereby facilitating decision making that better aligns the interests of the corporation and society.

\subsection{Macro Policy Rationale for Corporate Social Performance Reporting}

Financial markets have demonstrated the risk of misaligned incentives that may lead corporations to engage in risky activities that are adverse to the interests of long-term 
investors and society. The classic Berle-Means model of the corporation identified such conflicts, particularly the conflict between the separation of ownership from control and the role of the corporate director as mediator of varied social interests. ${ }^{12}$ Securitization and fund management are forms of financial intermediation that result in the separation of "ownership from ownership", meaning that the ultimate beneficial owners of securities do not assume responsibility for corporate conduct. ${ }^{13}$

Despite (or in response to) such conflicts, the majority of major global companies have adopted some form of ESG reporting into their corporate governance practices. A recent survey of the reporting practices of the 250 largest corporations in the world indicated the following most-cited motivations for social reporting (in order): ${ }^{14}$

- Ethical considerations 69\%

- Economic considerations 68\%

- Reputation or brand 55\%

- Innovation and learning 55\%

- Employee motivation 52\%

- Risk management or risk reduction 35\%

- Strengthened supplier relationships 32\%

- Access to capital or increased shareholder value $29 \%$

- Market position (market share) improvement 22\%

- Improved relationships with governmental authorities $21 \%$

- Cost savings $17 \%$

Implicit in this trend towards enhanced disclosure is a perception that stakeholder identification and engagement is important to corporate success. In this sense, corporate social performance reporting has become an important management process. It is seen as an instrument by which corporations can constructively engage with stakeholders, raise awareness and improve decision-making.

Corporate Social Performance - Example \#3 - Northgate Minerals and the Kemess North Project

A third case demonstrating the materiality of social performance involves Northgate Minerals Corporation and its planned Kemess North Project in British Columbia, located on land claimed by the Tse Keh Nay and the Gitxsan House of Nii Kyap First Nations. Since 2004, the First Nations expressed serious concerns regarding the potential negative impacts of the project on the environment and on their ability to fish, hunt, and continue their traditional spiritual practices near the proposed development site. They were particularly concerned with what they alleged was an inadequate consultation process regarding the company's development plans.

In September 2007, a Joint Review Panel concluded that the mine "in its present form" would not be in the public interest. The panel stated that any economic and social benefits from the project were outweighed by its long-term risks to the environment and by its social and cultural impacts on Aboriginal people. It recommended to federal and provincial environment Ministers that the project not be permitted.

Following the announcement, Northgate Mineral's share price fell by 45 cents to $\$ 2.78$, reducing the value of the company by $\$ 740$ million.

In November 2007, the company announced that it was writing off its investment in the Kemess North project "as a result of the Panel's report." (See Northgate Minerals Corporation, News Release, Nov. 5, 2007.)

12 A. Berle \& G. Means, The Modern Corporation and Private Property (New York: Harcourt Brace, 1967).

13 Leo E. Strine Jr., "Why Excessive Risk-Taking is not Unexpected" (October 5, 2009), online: New York Times Deal Book Dialogue http://dealbook.blogs.nytimes.com/2009/10/05/dealbook-dialogue-leostrine/

14 "International Survey of Corporate Responsibility Reporting" (2009), online: KPMG <www.kpmg.com 
It is in this context that various supranational non-governmental standard setters considering the issue of social reporting have embraced reporting frameworks that go beyond short-term impacts on the market valuation of corporate securities. For example, the AccountAbility AA1000 framework, discussed below in section 5.2.4, uses the principle of "inclusivity" which is defined by an organization's commitment to identify, Materiality of engage with and respond to stakeholders, and account for performance. ${ }^{15}$ Through engagement with stakeholders, companies are better able to determine "materiality" (defined more broadly than effect on short-term market price) based on an assessment of an issue's relevance and importance to legitimate stakeholders.

The forthcoming International Standards Organization ("ISO") 26000 standard, discussed below in section 5.2.5, focuses on integrating seven core ESG subjects throughout an organization: governance, human rights, labour practices, environment, fair operating practices, consumer issues and community involvement/development.

The ISO 26000 standard views internal and external communication as critical for:

- demonstrating accountability and transparency;

- helping to engage and create dialogue with stakeholders;

- addressing legal and other requirements for the disclosure of information related to social responsibility;

- showing how the organization is meeting its commitments on social responsibility and responding to the interests of stakeholders and expectations of society in general;

- raising awareness both within and outside the organization on its strategies and objectives, plans, performance and challenges for social responsibility;

- providing information about the impacts of the organization's activities, products and services, including details of how the impacts change over time;

- helping to engage and motivate employees and others to support the organization's activities in social responsibility;

- facilitating comparison with peer organizations, which can stimulate improvements in performance on social responsibility; and

- enhancing an organization's reputation to responsible action, openness, integrity and accountability, to strengthen stakeholders' trust in the organization.

Social reporting has become a useful starting point for engaging with stakeholders, creating goodwill and a "safe space" for dialogue which, over time, informs internal decision-making. Such engagement provides a critical framework for assessing and managing risks and opportunities on a regular basis. This, in turn, can drive performance, enhance an organization's reputational franchise and relational capital and increase opportunities for collaboration.

For example, in recently launching their worldwide sustainable product index, the Chief Executive Officer of Walmart stated: 
Customers want products that are more efficient, that last longer and perform better. And increasingly they want information about the entire life-cycle of a product so they can feel good about buying it. They want to know that the materials and the product are safe, that it was made well and that it was produced in a responsible way. We do not see this as a trend that will fade. High customer expectations are a permanent part of the future. ${ }^{16}$

In response, Walmart is surveying more than 100,000 suppliers around the world and is seeking to partner with others (suppliers, retailers, NGOs, governments and universities) to develop a global database of sustainability information on the life-cycle of products.

The collaboration extends beyond business-led initiatives for social reporting and engagement. Several countries, including Canada ${ }^{17}$ and Denmark, ${ }^{18}$ have identified corporate social reporting as a cornerstone in building comparative and competitive social advantage on a national scale, by enhancing national as well as institutional reputations, attracting employees, better meeting customer demands and contributing to the long-term legitimacy of market enterprise.

\section{Materiality of Employee Satisfaction - Example \#4 - Edmans Study}

Alex Edmans of the Wharton School conducted research on a specific aspect of social performance: employee satisfaction. His research, published in 2007, involved an analysis of the share price performance of companies on Fortune magazine's "Best Companies to Work For" list between 1998 and 2005. According to the Edmans study, an equal-weighted portfolio containing these companies outperformed the market even after adjusting for differences among the companies with respect to size, valuation, and momentum. Edmans found unexplained and statistically significant alpha of $+0.52 \%$ and, on the basis of his findings, concluded that "employee satisfaction is positively related to corporate performance...the findings imply that the market fails to incorporate intangible assets fully into stock valuations - even if the existence of such assets is verified by a widely respected survey."

Edmans, Alex. Does the Stock Market Fully Value Intangibles? Employee Satisfaction and Equity Prices. MIT Working Paper, 2007.

Financial statements "capture less than $20 \%$ of corporate risks and value creation potential, with the balance deriving from intangible factors such as human capital and resource sufficiency" ${ }^{19}$ It is in this context that social reporting can be understood to be critical, not just for investors but for a broader group of stakeholders, including:

- Employees - non-financial information is critical to defining an organizational culture, both for current employees and potential recruits;

- Consumers - as noted earlier, consumers drive demand and their expectations are rising; conversely, it has become apparent that consumers (and other stakeholders) take action against companies they do not trust; ${ }^{20}$

- Business Partners - corporations are increasingly moving beyond informing organizations in their value chains of their activities as a way to promote such relationships and moving towards using social reporting to engage business partners in finding solutions to social and environmental problems;

\footnotetext{
16 Mike Duke (CEO of Walmart) prepared remarks in announcing Walmart's sustainable produce index, July 16, 2009.

17 See section 4.4 .2 below.

18 "Reporting on Corporate Social Responsibility" (2009), online: Danish Commerce and Companies Agency www.csrgob.dk

19 EuroSIF (supported by the Federation of European Accountants) public policy position paper related to sustainable and responsible investment (April 14, 2009).

20 "2009 Edelman Trust Barometer" (2009), online: Edelman http://www.edelman.com/trust/2009/
} 
- Governments and Regulatory Agencies - demonstrating positive societal contributions made by business is critical in striking the right balance in a market enterprise economy and ensuring the success of any particular corporation; and

- Civil Society Organizations - which are typically interested in detailed information relating to specific topics, challenging the depth and breadth of a corporation's social reporting.

Ultimately, engaging with these diverse stakeholders may facilitate corporate strategy. Building relationships and better understanding the corporate social impacts can facilitate identification and improved decision-making around such issues. Typically, telling the story demonstrates the relevance of sustainability and leads to positive behavioural change and greater integration of sustainability issues into corporate decision-making

\section{Questions:}

- Are there other legitimate reasons for enhanced social reporting besides the interests of investors and the policy objectives discussed above?

- Do specific elements of social reporting require additional attention over others?

\section{CHALlenges OF CORPORATE SOCIAL PERFORMANCE DISCLOSURE}

While the investor and macro policy interests in greater transparency with respect to corporate social performance are compelling, there are legitimate concerns and challenges for issuers associated with enhanced disclosure requirements. Such concerns include:

- Costs: Enhanced disclosure requirements impose added costs on issuers. A salient issue is the extent to which enhanced disclosure requirements would apply to small and medium enterprises, or whether such requirements would be limited to larger issuers. Such concerns must be balanced by the interest in consistency and fairness between issuers in respect of disclosure obligations.

- Board Discretion: Regulatory oversight of any corporate activity brings with it the risk of impeding the freedom of boards and managers to make decisions in the best interests of the company. Companies may have legitimate reasons (such as cost, materiality etc.) for not committing corporate resources to reporting on corporate social performance. A related concern with prescriptive approaches to regulating social performance disclosure is that it could inhibit the ability of boards to respond to the identified interests and needs of stakeholders. In contrast, principled approaches, if too broad, could have limited effect in terms of enhancing disclosure.

- Competitive (Dis)Advantage: Enhanced corporate social performance transparency requirements could put Canadian issuers at a disadvantage to their international counterparts by imposing added constraints on Canadian companies operating abroad that may not apply to their competitors.

The foregoing challenges are relevant to the question of whether enhanced corporate social performance disclosure requirements are desirable, and how such requirements should be formulated. 


\section{Questions:}

- What other concerns exist for issuers in respect of enhanced disclosure requirements?

- Should differently situated companies be treated differently, or exempted from requirements altogether?

- Do the costs of enhanced disclosure outweigh the benefits?

- To what extent should requirements be prescriptive rather than based on principles?

- What other considerations should guide regulators in deciding whether and how to require enhanced disclosure of corporate social performance?

\section{LEGAL AND GOVERNANCE CONTEXT}

The following sections review the broader regulatory and governance context within which the social reporting and disclosure debate takes place.

\subsection{Statutory and Fiduciary Duties}

The legal standards applicable to corporate directors and fund managers are relevant to the question of how the measurement and reporting of corporate social performance can factor into managerial or investment decisions.

\subsubsection{Duties of Corporate Directors}

The Canadian Business Corporations Act (the "CBCA") requires directors and officers of corporations to act in the "best interests of the corporation". A question has arisen in Canadian jurisprudence whether or to what extent this duty permits or necessitates consideration of the interests of stakeholders other than shareholders. In the case of Peoples v. Wise, the Supreme Court of Canada confirmed that it is legitimate for corporate directors to take into consideration a broad array of interest and factors when determining and acting in the best interests of the corporation, including shareholders, employees, suppliers, creditors, consumers, governments and the environment. In the more recent decision of $B C E$ Inc. v. 1976 Debentureholders, the Supreme Court of Canada indicated that a board's consideration of conflicting interests should involve the ideal of the "responsible corporate citizen". It is clear that under Canadian corporate law boards may take into account CSR considerations, and in some circumstances may be required to do so. ${ }^{21}$

\subsubsection{Fiduciary Duties of Investment Managers}

While corporate directors are held to statutory standards of care, skill and loyalty, fund trustees are arguably subject to higher "fiduciary" standards including, for example, a duty of impartiality, which requires them to "identify, respect and balance the various interests" of different participant and beneficiary groups. ${ }^{22}$ 
The international understanding of investment manager fiduciary duties has been expanding to include the permissibility of ESG considerations when making investment decisions. This issue was the focus of a 2005 report entitled $A$ legal framework for the integration of environmental, social and governance issues into institutional investment as commissioned by the AMWG. The report, prepared by the international law firm Freshfields Bruckhaus Deringer, reviewed nine legal jurisdictions (including Australia, Canada, France, Germany, Italy, Japan, Spain, the United Kingdom, and the United States), and concluded that integrating ESG considerations into an investment analysis to more reliably predict financial performance is clearly permissible, and arguably required, as part of an investment manager's fiduciary duty in all reviewed jurisdictions. ${ }^{23}$

An update to this report was released by the AMWG in July 2009. Entitled Fiduciary Responsibility: Legal and practical aspects of integrating environmental, social and governance issues into institutional investment, the report argues that "advisors to institutional investors have a duty to proactively raise ESG issues within the advice that they provide, and that a responsible investment option should be the default position." In a recent survey conducted for Investment \& Pensions Europe (IPE), about 70\% per cent of respondents - who collectively manage $€ 197.6 \mathrm{bn}$ in assets - believe that it is the duty of trustees to consider ESG factors when making investment decisions and selecting managers. ${ }^{24}$

\subsection{Canadian Securities Law and Regulation}

Publicly listed Canadian companies are subject to provincial securities disclosure obligations. National Instrument 51-102 - Continuous Disclosure Obligations ("NI 51-102") sets out the ongoing disclosure requirements of reporting issuers (other than investment funds). In addition, the Management Discussion and Analysis ("MD\&A") Form and the Annual Information Form ("AlF") guide the filings of issuers. Generally, the MD\&A and AlF direct companies to focus on the disclosure of "material information".

The Ontario Securities Act provides a definition of materiality that encompasses the "market impact" standard, which requires that information should be disclosed if it has the potential to move share price. A "material fact" is one that would reasonably be expected to have a significant effect on the market price or value of securities. A "material change" pertains to a change in the business, operations or capital of an issuing company, or decision to make such a change, that would reasonably be expected to have a significant effect on the market price or value of any securities of the issuer.

Other elements of securities regulation appear to adopt a different standard. For example, the instructions for Annual Information Form disclosures 25 uses the "reasonable investor" standard of materiality. Under that standard, information is material if the decision of a reasonable investor to buy, sell or hold securities of a company would be influenced if the information was omitted or misstated.

Under either standard of materiality, the MD\&A Form should contain information that may not be fully reflected in financial statements, including a discussion of important trends and risks that have affected corporate performance or which are reasonably likely to affect it in future. An AlF should provide material information about the company and its business at a point in time in the context of its historical and possible future development, and describe the issuer, its operations and prospects, risks and other external factors that impact the company.

23 "A Legal Framework for the Integration of Environmental, Social and Governance Issues into Institutional Investment" (2005), online: UNEP FI Asset Management Working Group http://www.unepfi.org/fileadmin/documents/freshfields_legal_resp_20051123.pdf

24 Online: http://www.responsible-investor.com/home/article/ri_round_up_october_5/P1

25 Form 51-102F2. 
NI 51-102 specifically requires issuers to disclose in the AIF any environmental and health risks relating to the company or its business that would be most likely to influence an investor's decision to purchase its securities. NI 51-102 also requires that if a company has implemented social or environmental policies that are fundamental to its operations, it describe such policies and the steps it has taken to implement them. There does not, however, appear to be an obligation to make a statement where the issuer has not implemented social or environmental policies. ${ }^{26}$

\section{Questions:}

- Is there a need to redefine or clarify statutory standards for directors or fund managers?

- Is this securities law materiality standard sufficient to ensure adequate disclosure?

- If not, what regulatory changes should be introduced to enhance disclosure and reporting on corporate social performance?

\subsection{Non-Securities Oversight of Corporate Social Performance in Canada}

Aside from securities reporting obligations aimed at investors, Canadian companies may be required by law or regulation to disclose information and proactively develop policies and practices regarding corporate social performance in relation to other relevant stakeholders. Below are some examples of specific corporate social performance requirements that already exist in Ontario relating to employment standards, labour relations, occupational health and safety, human rights, and pay equity.

\subsubsection{Employment Standards}

Employment standards legislation in Ontario sets minimum expectations for employers in respect of employment terms and conditions and, in some instances, requires reporting and disclosure of employment related information to interested stakeholders. For example, the Ontario Employment Standards Act, 2001 (the "ESA") requires employers who intend to terminate more than 50 employees within a four-week period to file with the Ministry of Labour information concerning the economic circumstances surrounding the termination, whether alternatives to termination were considered, and whether any such alternatives were implemented by the company. ${ }^{27}$ The Ministry can request further information from the company and shares the filings with the Ministry of Training, Colleges and Universities for the purposes of providing a range of programs and services to help workers make a rapid and effective transition to new employment. Such information must also be posted in the workplace. Failure to report in accordance with the requirements of the ESA in a timely manner could prevent the company from carrying out the proposed terminations.

\subsubsection{Labour Relations}

Corporate employers may be required to disclose during collective bargaining any decisions that have been made that could have a significant impact upon the bargaining unit. This could include plant closures, planned relocations or layoffs. Failure to adequately disclose such 
information could constitute an unfair labour practice contrary to the Ontario Labour Relations Act, 1995. Collective agreement language may also specifically require companies to consult with unions when making decisions involving significant operational change that would affect members of the bargaining unit.

\subsubsection{Occupational Health and Safety}

The Occupational Health and Safety Act (the "OHSA") requires companies to be proactive and take "every reasonable precaution" to ensure the health and safety of employees and imposes liability on the directors of companies for the health and safety of employees. This necessitates evaluation of health and safety hazards, the proactive adoption of safety policies, practices, and procedures to mitigate the risks that they present. Certain practices and procedures are prescribed while others may be left up to individual companies to determine. As well, companies are required to establish joint health and safety committees composed of both company and employee representatives that may identify workplace hazards and facilitate the effectuation of health and safety practices. This creates a structured role for interested stakeholders in the health and safety practices of the company.

While public reporting is not typically part of such health and safety obligations, the requisite compliance monitoring processes necessitate the disclosure of policies and practices, performance history, and information respecting specific incidents. Where incidents occur, reporting requirements arise, both under the OHSA as well as the Ontario Workplace Safety and Insurance Act.

\subsubsection{Human Rights}

Companies are expected to take a proactive approach in addressing human rights issues in relation to their stakeholders, particularly employees, under the Ontario Human Rights Code (the "code"). The Code requires employers to ensure that employment practices do not result in discrimination on the basis of protected grounds such as gender, race, or disability. The Code does not directly require companies to publicly report on human rights practices, but such practices may be reviewed in the course of litigation arising under the code.

\subsubsection{Pay Equity}

The Pay Equity Act may require corporate employers to implement plans that address gender bias in pay scales, and report results to employees, workplace unions and governmental authorities. Compliance will often necessitate posting pay equity plans in the workplace as well as sharing such plans with unions and governmental authorities

\section{Questions:}

- Should compliance with such issue-specific regulatory requirements be the subject of enhanced corporate social performance disclosure?

- Are the current disclosure and reporting obligations of these issue specific regulatory regimes adequate to meet the legitimate needs of relevant stakeholders? 


\subsection{Sector Specific CSR and Reporting Requirements in Canada}

\subsubsection{Public Accountability Statements}

Regulated financial institutions with over \$1 billion in equity are specifically required to publish annually a "Public Accountability Statement" ("PAS") describing their contributions and that of their affiliates, to the Canadian economy and society. The PAS reporting requirement arises from the Bank Act, the Insurance Companies Act, and the Trust and Loan Companies Act. Regulations to these federal statutes prescribe the contents of PAS reports and the timing of their publication. While not required to do so,

PAS reports often go "beyond compliance" and report on matters relating to negative, as well as positive, impacts of corporate activities on the Canadian economy and society. ${ }^{28}$

\section{Questions:}

- Should the PAS approach be extended to other issuers?

\subsubsection{Federal CSR Strategy for the Canadian International Extractive Sector}

In March of 2009 the Government of Canada introduced a new policy entitled Building the Canadian Advantage: A CSR Strategy for the Conadian International Extractive Sector (the "CSR Strategy"). The (SR Strategy was the culmination of a series of national roundtables ("Roundtables"), led by the Department of Foreign Affairs and International Trade, on CSR issues in the mining, oil and gas sectors and their operations in developing countries. The objective of these Roundtables was to examine measures that could be taken to position Canadian extractive sector companies operating in developing countries to meet or exceed leading international CSR standards and best practices.

Four policy initiatives have been announced by the Canadian Government as part of the CSR Strategy:

1) establishment of a "CSR Counselor" office to act as a neutral, impartial and objective reviewer of requests to undertake informal mediation and fact-finding related to the activities of Canadian extractive companies, in Canada or abroad. The first CSR Counselor was appointed in October of 2009;

2) creation of a new centre of excellence to be housed within the Canadian Institute of Mining, Metallurgy and Petroleum;

3) provision of ongoing assistance from the Canadian International Development Agency to help foreign countries develop their capacity to manage natural resources; and

4) promotion of internationally recognized, voluntary guidelines for CSR performance and reporting.

It is not yet clear the extent to which these policy objectives will entail regulation, or how existing securities or other disclosure and reporting rules may be affected in the implementation of the CSR Strategy. It should be noted that certain recommendations from the Roundtables are not part of the current CSR Strategy, including the withholding of 
government services, such as financial and insurance support provided by Export Development Canada, from companies in serious violation of CSR standards, or mandatory disclosure by federally regulated pension funds of the extent to which they utilize corporate social performance metrics in making investment decisions. ${ }^{29}$

\section{Questions:}

- Does the CSR Strategy reflect a trend towards regulatory or legislative oversight of corporate social performance?

- Should the CSR Strategy be extended to other sectors?

\subsection{International Legal and Regulatory Context}

\subsubsection{United States}

The United States Securities Exchange Commission ("SEC") Regulation S-K sets out materiality based reporting requirements for issues that may affect a company's financial prospects. Stakeholder issues, including consumer campaigns and boycotts, could fall within the scope of this provision. The SEC has interpreted item 303 Regulation S-K (disclosure of known trends, demands, commitment, events or uncertainties that are reasonably likely to affect operational or financial performance) to mean that if there is a reasonable likelihood but some uncertainty about the probabilities regarding such trends, etc., a reporting firm should err on the side of disclosure.

The Sarbanes-Oxley Act of 2002 requires CEO and CFO certification of internal controls that assure the identification of material risks, which could include social risks. Aside from these general requirements, there are few specific ESG disclosure or reporting requirements. This state of affairs, however, may be changing. In response primarily to the climate change debate, the SEC Investor Advisory Committee met with stakeholders in the summer of 2009 to discuss disclosure of ESG issues. In particular, the following issues were discussed:

- Whether investors consider sustainability issues important in making investment or voting decisions;

- Whether current disclosure practices on sustainability are sufficient for investors to make informed investment and voting decisions;

- If additional disclosure would be useful, whether changes are needed in guidance forms or regulations, or in the provision of greater instruction and oversight of disclosure within the current regime.

Some members of the committee have indicated their view that traditional reporting and accounting do not capture many important issues and that broadening disclosure to more meaningfully include ESG considerations would better reflect the real value of an issuer and the risks that they face. 


\subsubsection{European Union}

Despite a 2001 "Green Paper" issued by the European Union that emphasized the "voluntary" nature of CSR obligations, the European Union has generally been seen as a "stronghold" for CSR law and policy. This has been said to reflect a more corporatist history of business management within some European Union countries. For example, European jurisdictions have tended to enshrine corporate governance structures that are designed to mediate various competing interests and stakeholder constituencies, giving them a greater role in the management of business. ${ }^{30}$

While the effectuation of CSR law and policy generally, and corporate social performance disclosure obligations in particular, is done primarily at the national level, the European Community has supported "triple bottom line" reporting and detailed environmental disclosure. In 2002 the European Union adopted the Accounts Modernisation Directive (2003/51/EC) which advised member states to require financial reporting to include risk assessments that take into consideration non-financial key performance indicators including information relating to environmental and employee matters.

\subsubsection{France}

In 2001, mandatory corporate environmental and social disclosure was legislated in France. French corporations listed on the Premier Marché are required to annually report on the social and environmental impact of their activities. Social and community factors that must be disclosed include:

- recruitment and workforce utilization;

- use of permanent versus temporary labour or subcontracted labour;

- overtime;

- staff reductions and employment safeguard plans;

- work hours;

- wages and welfare costs;

- gender parity in wages and benefits;

- industrial relations;

- health and safety conditions;

- integration of disabled workers;

- territorial impact;

- community relationships;

- community development.

The legislation has been criticized for lacking sanctions for non-compliance. A 2003 study found that two thirds of listed French companies reported on only $40 \%$ of the required indicators. A 2005 study indicated that reporting practices had improved. ${ }^{31}$ 


\subsubsection{United Kingdom}

In 2006, new environmental and social reporting requirements for U.K. based public companies were introduced as part of the Companies Act, 2006. Directors' statutory duties were modified to require them to consider the company's effects on a range of social and environmental matters. ${ }^{32}$ As part of the mandatory "business review" that forms part of annual financial reporting, companies must report on their social and environmental risks and opportunities for their shareholders, as well as on employee matters and risks down supply chains. ${ }^{33}$ The statute allows companies not to report on social and environmental issues so long as it so states. This broad caveat to social and environmental reporting makes such reporting essentially voluntary. ${ }^{34}$ U.K. legislation also requires trustees of U.K. occupational pension funds to disclose the extent (if at all) to which social, environmental or ethical considerations are taken into account in the selection, retention and realization of investments, and policies regarding rights attached to such investments. Studies have indicated widespread noncompliance with these requirements among U.K. pension plan trustees. ${ }^{35}$

\subsubsection{Norway and Denmark}

Since 1999, Norway's Accounting Act has required company directors in the annual directors' report to report on certain social and environmental issues. Companies are required to provide information on the internal workplace regarding injuries and accidents, absences due to illness, gender equality and discrimination. There are no legislated penalties for noncompliance, and studies have shown that only $10 \%$ of companies comply with the full extent of the disclosure obligations set out in the Accounting Act. $3^{6}$

0n December 16, 2008, the Danish Parliament adopted the proposed "Act amending the Danish Financial Statements Act (Report on social responsibility for large businesses" (the "Danish Act"). Under the Danish Act, large Danish companies (whether or not listed) must include information on their CSR policies and practices in their annual reports, including disclosure of standards, guidelines ог principles; how such policies are being implemented (including monitoring and compliance systems), and achievements resulting from CSR work during the financial year, and any related future implications for the company. ${ }^{37}$ Such information is subject to audit.

\subsubsection{South Africa}

Following initial recommendations from the King Committee on Corporate Governance in 2002, all companies with securities listed on the Johannesburg Securities Exchange, financial entities, public sector enterprises and agencies are now subject to the principles stipulated in a Code of Corporate Practices and Conduct. This code requires applicable companies to report annually on the nature and extent of social, transformation, ethical, safety, health and environmental management policies and practices. The determination of relevance is left to corporate boards to consider in light of the particular circumstances of the company and is intended to promote stakeholder engagement (and trust) and better risk management. Compliance with the code is not mandatory, but companies are required to report the extent of their compliance. This allows for market and public evaluation of corporate reporting practices. The code places emphasis on issues such as economic empowerment, HIV/AIDS awareness and other non-financial information of particular relevance South African society. ${ }^{38}$

\footnotetext{
32 Companies Act, 2006, s. 172.

33 Ibid., s. 417.

34 Ibid at 260.

35 Kerr, Janda, Pitts at 263.

36 Ibid. at 264.

37 Ibid at 265.

38 Ibid at 262.
} 
A third King Committee report was released in 2009 ("King III"). King III recommends integrated sustainability performance and integrated reporting to enable stakeholders to make a more informed assessment of the economic value of a company. The integrated report should have sufficient information to record how the company has positively and negatively impacted on the economic life of the communities in which it operated during the year under review. Further, it should report how the board believes that in the coming year it can improve the positive aspects and eradicate or ameliorate the negative aspects, in the coming year. ${ }^{39}$

\section{Questions:}

- To what extent should practices of other jurisdictions influence Canadian securities regulators?

- In light of these international examples, should Canadian securities and corporate laws be changed to encourage and enhance disclosure requirements?

- Should stock exchanges or other appropriate standard setters play a role in promoting social performance measurement and disclosure, and if so what should it look like?

- Are there competitive advantage/disadvantage issues at play that should be considered in considering whether to legislate or otherwise promote further disclosure requirements?

\section{SUPRANATIONAL INITIATIVES}

\subsection{United Nations}

\subsubsection{Global Compact}

The Global Compact is structured as a voluntary governance initiative between the UN and corporate participants and exists to assist the private sector in the management of increasingly complex risks and opportunities in the environmental, social and governance realms. The Global Compact provides a policy framework for the development, implementation, and disclosure of sustainability principles and practices, as encompassed by ten principles:

\section{Human Rights}

- Principle 1: Businesses should support and respect the protection of internationally proclaimed human rights; and

- Principle 2: make sure that they are not complicit in human rights abuses.

\section{Labour Standards}

- Principle 3: Businesses should uphold the freedom of association and the effective recognition of the right to collective bargaining;

- Principle 4: the elimination of all forms of forced and compulsory labour; 
- Principle 5: the effective abolition of child labour; and

- Principle 6: the elimination of discrimination in respect of employment and occupation.

Environment

- Principle 7: Businesses should support a precautionary approach to environmental challenges;

- Principle 8: undertake initiatives to promote greater environmental responsibility; and

- Principle 9: encourage the development and diffusion of environmentally friendly technologies.

Anti-Corruption

- Principle 10: Businesses should work against corruption in all its forms, including extortion and bribery.

The Global Compact incorporates a policy known as the Communication on Progress ("COP") that requires the annual posting by corporate participants of information regarding Compact issue areas. Participating companies are required to follow this policy, as a commitment to transparency and disclosure is critical to the success of the initiative. Failure to communicate will result in a change in participant status and possible delisting from the Compact. ${ }^{40}$

\subsubsection{UNEP FI Asset Management Working Group}

The AMWG was formed in 2003 with the purpose of advancing the integration of ESG factors into investment decision-making. A significant theme in its research and its findings is the need for more detailed and more standardized corporate reporting on ESG performance. The AMWG's first major report, The Materiality of Social, Environmental and Corporate Governance Issues to Equity Pricing, noted that "[t]he majority of analysts noted difficulties in comparative analysis due to the range of reporting practices for environmental, social and corporate governance risks and opportunities." One of the key findings of the report is that inadequate reporting is often a barrier to ESG analysis, and in the report the AMWG calls on regulatory bodies to "update financial disclosure regulations for companies and stock exchanges to require specific disclosure of environmental, social and corporate governance criteria." ${ }^{41}$

\subsubsection{United Nations Conference on Trade and Development}

The United Nations Conference on Trade and Development ("UNCTAD"), through the International Standards of Accounting and Reporting ("ISAR") working group, has also done extensive work in the area of corporate social performance reporting. ISAR has conducted a number of studies on corporate responsibility reporting practices. The most recent of these was a 2008 review of corporate responsibility reporting which examined the reporting practices of 100 enterprises from 10 emerging markets. This study was complemented by a 2008 review of the corporate responsibility performance of large emerging market enterprises. In November 2008, UNCTAD signed a Memorandum of Understanding with the Global Reporting Initiative (discussed below). This new initiative is aimed at promoting in developing countries and transition economies greater understanding of, and greater participation in, the processes that set internationally recognized sustainability reporting standards.

\footnotetext{
40 "Overview of the UN Global Compact" (2009), online: Global Compact http://www.unglobalcompact.org/AboutTheGC/>.

41 "The Materiality of Social, Environmental and Corporate Governance Issues to Equity Pricing" (2004), online: AMWG http://www.unepfi.org/work_streams/investment/amwg/ at p. 5.
} 


\subsection{Other Voluntary Initiatives}

During the last several years there have emerged a number of initiatives and organizations that are either investor or issuer led and that address corporate social performance reporting. A few of these initiatives are outlined below.

\subsubsection{Global Reporting Initiative}

The Global Reporting Initiative ("GRI") is an independent, multi-stakeholder network which has developed a voluntary sustainability reporting framework. Launched in 1997, the GRI Framework was developed (and continues to evolve) via a multi-stakeholder process involving industry, investors, civil society and labour, and has emerged as the de facto standard for CSR reporting. It comprises universally-applicable reporting principles, guidance and indicators for organisations of all sizes and sectors. The GRI has also developed sector supplements, including for the mining and metals sector, to help standardize reporting criteria and indicators to the operational context of specific industries. The GRI is followed by over 1,500 companies globally. The GRI has also played a role in government legislation of corporate social performance reporting. In 2007 the Swedish Government announced that all Swedish state owned companies must file an annual sustainability report based on the GRI "G3" guidelines each year beginning in 2009.

The GRI's reporting framework sets out principles and indicators that organizations can use to measure and report their economic, environmental, and social performance. Under the GRI "material information" covers topics and indicators that reflect the organization's significant economic, environmental and social impacts or that would substantively influence the assessments and decisions of stakeholders. The GRI does not evaluate the accuracy of reports and has no enforcement mechanisms.

\subsubsection{Extractive Industries Transparency Initiative}

The Extractive Industries Transparency Initiative ("EITI") is a multi-stakeholder initiative that aims to bring about greater transparency regarding the payment of taxes and royalties by resource extraction companies. Specifically, the initiative calls for the regular publication of payments made by companies to governments and revenues governments receive from companies; independent auditing and reconciliation using international standards; the involvement of civil society in design, monitoring and evaluation; and the development of a public and financially sustainable work plan by each host government.

Investors, especially institutional investors, have been integral stakeholders and participants in the EITI. Recognizing that enhanced transparency can mitigate investment risk in the extractive industries, over 80 institutional lenders and investors, representing US\$16 trillion, have officially endorsed the initiative and signed the Investors' Statement on Transparency in the Extractives Sector, which calls on companies to support the principle of payments disclosure and to work proactively with host country governments and other stakeholders to promote, develop and implement transparency agreements.

\subsubsection{Equator Principles}

The Equator Principles ("EPs") are a set of 10 principles for managing environmental and social risks in project finance. The EP were negotiated and developed by banks with participation from other relevant stakeholders. The EPs were first agreed to in June, 2003, by 10 banks and 
subsequently revised in 2006. From 2003 to 2006, over 40 additional financial institutions signed on to the EPs. As of April 30, 2009, 67 financial institutions had adopted the EPs, including all of the five major Canadian banks.

The EPs act as a baseline or minimum benchmark for each member institution's own internal social and environmental policies, procedures and standards. A primary goal of the EPs is to "avoid the negative impacts on project-affected eco-systems and communities and, if impacts are unavoidable, to minimize effects or appropriately compensate for them". The EPs apply to projects across all industry sectors with a capital cost of US\$10 million or more. They also affect member institutions' advisory activities, purporting to make clients aware of the content, application and benefits of applying the EPs to an anticipated project.

\subsubsection{AccountAbility's AA1000 Standard}

AccountAbility's AA1000 ("AA1000") series are principles-based standards that can be used by any type of organization from multinational businesses, to SMEs, governments and civil society organizations. The standards were developed through multistakeholder consultation processes. The AA1000 AccountAbility Principles Standard 2008 provides a framework for an organization to use in order to identify, understand, prioritize and respond to sustainability challenges. The AA1000 Assurance Standard 2008 is a leading international standard used to provide assurance on publicly available sustainability information, particularly CSR/Sustainability reports. The AA1000 Stakeholder Engagement Standard 2005 provides a framework to help organizations with respect to stakeholder engagement processes. ${ }^{42}$

\subsubsection{ISO 26000}

The ISO established a working group in 2005 to develop a standard setting out guidelines on CSR practices. The objective was to produce a guidance document, written in plain language that is understandable and usable by non-specialists, and not a specification document intended for third party certification. The new standard has been designed to co-exist with, and not replace, existing inter-governmental agreements such as the United Nations Universal Declaration of Human Rights, and those adopted by the International Labour Organization. To this end the ISO has engaged in a process to receive input by stakeholders with a serious interest in CSR and corporate social performance including: industry, government, labour, consumers, nongovernmental organizations, in addition to geographical and gender-based balance. The standard is targeted for final publication in $2010 .{ }^{43}$

\section{Questions:}

- Are voluntary initiatives, such as those outlined above, sufficient to meet the needs of shareholders and other relevant stakeholders for corporate social performance disclosure?

- Can or should regulators mandate or promote private voluntary frameworks for corporate social performance reporting and disclosure?

- Should public or private enforcement mechanisms be considered to promote the consistent implementation of corporate social performance measurement and reporting? 


\section{OPTIONS FOR REFORM}

Should reform of the existing regulatory and governance structure be found appropriate, the question becomes how this might be done. Based on the foregoing review, options for reform might include:

\subsection{Enhanced Reporting Requirements}

If existing disclosure requirements are deemed to be inadequate, Canadian securities regulators could craft new regulatory requirements for enhanced disclosure and reporting on corporate social performance by issuers of securities. The definition of "materiality" could be expanded to include indicators of corporate social performance. The existing disclosure requirements on large financial institutions that are required to publish annual Public Accountability Statements (see Section 3.4.1) could be used as a model for other securities issuers.

To effectuate such an approach, internal and external compliance monitoring systems could be put in place. Sanctions, penalties or other consequences for non-compliance could be implemented. This regulatory approach could be coupled with the amendment of nonsecurities legal and regulatory regimes affecting the corporation. This could include clarification of the scope of directors' and trustees' duties, and/or disclosure requirements for companies in respect of their employment, human rights, health and safety, or other practices that relate to corporate social performance.

As noted above, an important question would be the extent to which reporting requirements would be specifically prescribed, or whether only principles should be promulgated and actual decisions regarding materiality left to the entities themselves.

The summary by Eugene Ellmen of the Social Investment Organization, at Appendix B attached, describes two different proposals in this regard.

\subsection{Enhanced Compliance/ Enforcement with respect to Existing Disclosure Requirements}

If it is concluded that the existing definition of "materiality" for the purposes of Canadian securities law is adequate, then any shortfall in the disclosure of corporate social performance would simply be due to a lack of clarity on expectations, or lack of effective compliance/enforcement. In such a scenario, another option would be to enhance compliance/enforcement mechanisms, and the explanation of disclosure and reporting expectations within the existing scope of "materiality". This could be done through the clarification of disclosure expectations. Increased monitoring of disclosure practices, and the imposition of sanctions or penalties for non-compliance, could also be pursued to encourage enhanced disclosure.

\subsection{Promotion of Voluntary Best Practices}

Securities regulators or other governmental authorities could encourage voluntary adoption of enhanced reporting and disclosure by promoting best practices within the existing regime. This could resemble the CSR "centre of excellence" that is to be created by the Government of Canada (see Section 3.4.2) or endorsement of efforts such as the GRI. It could also involve the issuance of guidelines or the amendment of forms to instruct securities issuers on the proper 
reporting and disclosure of corporate social performance, within the existing definitions of "materiality". This could be coupled with enhanced compliance/enforcement, or could be purely voluntary in nature. Alternatively, incentives for enhanced corporate social performance disclosure and reporting could be developed.

\subsection{Enhanced Investor Disclosure Requirements}

Regulators could also establish enhanced disclosure and reporting requirements for investors themselves. In particular, institutional investors and pension funds could be required to publicly report on their investment practices, and the extent to which they use corporate social performance as an indicator for investment decisions. As with other options for reform, the question would be the extent to which disclosure would be prescribed or left up to the institutional investors and what consequences should exist for non-compliance.

\section{Questions:}

- Is reform of the current regime needed to enhance corporate social performance disclosure?

- What other options for reform are there?

- Which options should be acted upon?

- How should reform be carried out?

- To what extent are the initiatives discussed in sections 4.4, 4.5, 5.1 and 5.2 useful as models or components of reform?

- What are the benefits, risks and challenges associated with any attempts at reform?

- For issuers?

- For investors?

- For other stakeholders?

- Would it make sense to promote the creation of a "commission" on corporate social reporting with a view to advancing initiatives that can drive change?

- If so, where should it emerge from and how broad of a mandate might such a body be given?

\section{Contact us}

If you have any questions or comments, please contact:

\section{Ed Waitzer}

Director, Hennick Centre for Business and Law

Tel: 416.869 .5587

EWaitzer@schulich.yorku.ca

\section{Kevin Ranney}

Global Director, Responsible Investment Services, Jantzi-Sustainalytics

Tel: 416.861 .0403

kranney@jantzisustainalytics.com

\section{Archana Sridhar}

Associate Director, Hennick Centre for Business and Law

Tel: 416.736 .5490

asridhar@osgoode.yorku.ca 


\section{APPENDICES}

Appendix A - Laurel Broten resolution

Appendix B - "Mandated ESG Disclosure: A discussion paper on current proposals for regulatory reform" (executive summary), by Eugene Ellmen of the Social Investment Organization

\section{Appendix A - Laurel Broten resolution}

On April 9, 2009, the Ontario legislature voted unanimously to support a private member's resolution introduced by Liberal MPP Laurel Broten (Etobicoke-Lakeshore). The non-binding resolution calls on the OSC to conduct a consultation into best practices on corporate social responsibility (CSR) and environmental, social and governance (ESG) reporting standards. The resolution reads:

Be it resolved that, in the opinion of this House, the province of Ontario should undertake a review of Ontario's current corporate disclosure reporting requirements, standards and compliance therewith, with a particular emphasis on additional financial and non-financial information to ensure that Ontario investors have access to all information material to them in making investment decisions.

That, in undertaking such a review, the Ontario Securities Commission (OSC) should undertake a broad consultation with its own advisory bodies including the Continuous Disclosure Committee, concerned stakeholders, appropriate interest groups and individuals and other securities regulators, to establish best practice corporate social responsibility (CSR) and environmental, social and governance (ESG) reporting standards.

That the OSC seek to develop and adopt an enhanced standardized reporting framework for both quantitative and qualitative social and environmental information to ensure corporate disclosures are understandable, comparable and outcomefocused.

That the 0SC shall report back to the Minister of Finance no later than January 1 , 2010, with regard to its findings, together with recommendations for next steps to enhance disclosure. 
Appendix B - Mandated ESG Disclosure:

A discussion paper on current proposals for regulatory reform

Eugene Ellmen, Executive Director

Social Investment Organization

Executive summary

November 2009

\section{Background}

Pressure for mandatory corporate disclosure on environmental, social and governance (ESG) issues is growing around the world. The US Social Investment Forum (SIF) has issued a proposal for mandated ESG disclosure to the Securities and Exchange Commission (SEC) and the European Sustainable Investment Forum (Eurosif) has issued a proposal to the European Commission. This paper sets out the case for mandated ESG disclosure, and reviews these proposals and analyzes their strengths and weaknesses according to the key issues outlined in the case for mandated disclosure.

\section{Why mandated ESG disclosure is necessary}

In spite of significant legal and financial drivers encouraging the spread of responsible investment (RI) and large numbers of investors and collaborations improving RI research and practice, the development of responsible investment is hobbled by a lack of widespread, easily accessible, comparable and systematic information on the ESG performance of companies. The current situation is marked by low rates of voluntary corporate reporting on ESG issues and inconsistent reporting and presentation of data.

As a result of this lack of meaningful, systematic reporting on ESG issues, asset managers, fund companies and other investors are unable to obtain the information they need to conduct thorough, comprehensive analyses of companies. This failure is slowing the development of analysis and practice on responsible investment, and represents a significant barrier to the integration of ESG issues into mainstream investing.

Because underlying ESG risks of investment valuations are so poorly understood, there is significant risk that undisclosed ESG risk could have catastrophic market impacts. Such catastrophes are examples of so-called "black-swan events." Undisclosed ESG risk was one of the factors in the 2008 collapse of global credit markets. Mandatory disclosure of ESG risk factors would provide better understanding of such potentially-catastrophic underlying risk situations, helping to prevent them altogether or to mitigate their effects.

ESG information must be widely disseminated and easily accessible in the market. Therefore, mandatory ESG reporting is essential from both a long-term perspective of enhancing returns and reducing risk and a short-term perspective of identifying unusual but potentiallycalamitous possibilities. The costs to issuers of such reporting must be kept as low as possible, of course, but the benefits of mandatory ESG reporting to investors and society as a whole outweigh the costs to issuers.

\section{Review and analysis of the proposals}

The US proposal, outlined in a letter to SEC Chairman Mary Shapiro July 21, 2009 from SIF CEO Lisa Woll, contains two key recommendations: 1 ) that issuers should be subject to mandatory reporting under the highest reporting standard (G3 Guidelines A-plus) of the Global Reporting Initiative (GRI); and 2) that the SEC issue interpretive guidance to clarify sustainability-related disclosures required under Management's Discussion \& Analysis (MD\&A) filings. 
The European proposal, outlined in Eurosif's Public Policy Position Paper related to Sustainable and Responsible Investment (SRI), calls for mandatory ESG reporting through the use of "principles-based" key performance indicators (KPIs), some of which would be sector-specific. The recommended reporting framework should be genuinely informative and include forwardlooking elements; be material, relevant and timely; describe company strategy, risks and opportunities; be accessible and integrated; use key performance indicators (KPIs) that are linked to strategy and facilitate comparisons; use objective metrics; and be strengthened where possible by independent assurance. The key advantage of the US proposal is that it offers a clear, simple framework applied to all publicly-listed companies. It would encourage broad market reporting on ESG, thus increasing the amount of ESG information in the market. The clear rules of the GRI framework would facilitate comparability and systematic analysis.

The European proposal offers a better opportunity for leadership on ESG issues by companies or sectoral associations. This would provide the opportunity for forward-looking ESG indicators, providing a better early warning system about issues of undisclosed risk. This model would encourage companies and sectors to take leadership on ESG disclosure, rather than treating it as a compliance function. However, there is a risk that certain sectors would not be able to reach a consensus on appropriate KPIs, thereby leading to inconsistent reporting between sectors.

The US model would have higher compliance costs in the short-term, but the European model conceivably could have higher on-going costs because of the need for continuous review of the sectoral KPIs.

\section{Conclusions}

Inaction is not an option. While there are compliance and regulatory costs to both of these frameworks, the cost of doing nothing is prohibitive in the loss of investor opportunity, higher longterm risk and the risk of catastrophic ESG-related events.

The US approach of mandatory disclosure under the GRI would provide suitable broad market ESG information. The US approach would also ensure a level of systematic reporting enabling comparisons within sectors. The European approach has the benefit of encouraging companies and sectors to take leadership on ESG disclosure, bringing to light emerging issues and developing appropriate sectoral consensus on relevant indicators. While the European approach alone would not ensure broad market information, it does encourage sectors and companies to think in a forward fashion, and not simply to treat ESG disclosure as a compliance function.

If Ontario can take a hard look at these state-of-the-art proposals and choose the best of both, it could develop the best mandatory ESG reporting system in the world. If implemented nationally through a CSA continuous disclosure instrument, Canada could become the leading jurisdiction globally for ESG reporting. 


\section{APPENDIX D - LIST OF ATtendeES AT DECEMBER 7th ROUNDTABLE CONSULTATION}

\begin{tabular}{|c|c|}
\hline Jane Ambachtsheer & Mercer Investment Consulting \\
\hline Steve Astritis & Inmet Mining \\
\hline Brigid Barnett & Responsible Investing CPP Investment Board \\
\hline Nooreen Bhanji & Osgoode Hall Law School (student recorder) \\
\hline Laurel Broten & MPP Etobicoke-Lakeshore \\
\hline Peter Chapman & SHARE \\
\hline Valérie Chort & Deloitte \& Touche LLP \\
\hline Mary Condon & Ontario Securities Commission / Osgoode Hall Law School \\
\hline Michael Conway & Financial Executives International Canada \\
\hline Paul Costello & ACCA Canada and US \\
\hline Andy Crane & Schulich School of Business \\
\hline Julie Desjardins & Desjardins \& Associates \\
\hline Patrick Deutscher & Ministry of Finance \\
\hline Aaron Dhir & Osgoode Hall Law School, York University \\
\hline Iuliana Dutkay & Schulich School of Business (student recorder) \\
\hline Eugene Ellmen & Social Investment Organization \\
\hline Celese Fletcher & The Fletcher Consultancy \\
\hline Eleanor Fritz & Toronto Stock Exchange \\
\hline Bryan Husted & Schulich School of Business \\
\hline Michael Jantzi & Jantzi-Sustainalytics \\
\hline Patricia Koval & Torys LLP \\
\hline Chris Le Pan & Ministry of Finance \\
\hline Bob Mann & Jantzi-Sustainalytics \\
\hline Jo-Anne Matear & Ontario Securities Commission \\
\hline Karen McCarthy & Royal Bank of Canada \\
\hline Susan McGeachie & PricewaterhouseCoopers LLP \\
\hline Frank McShane & Talisman \\
\hline Valerie Pascale & Goldcorp \\
\hline Poonam Puri & Hennick Centre for Business and Law \\
\hline Kevin Ranney & Jantzi-Sustainalytics \\
\hline Alan Richardson & Schulich School of Business \\
\hline Stephanie Robertson & SiMPACT / LBG Canada \\
\hline Adam Segal & Sherritt International Corp. \\
\hline Ilana Singer & Canadian Foundation for Advancement of Investor Rights \\
\hline Sara Slinn & Osgoode Hall Law School \\
\hline Kerry Smuk & Office of Laurel Broten \\
\hline Archana Sridhar & Hennick Centre for Business and Law \\
\hline Michael Torrance & Ogilvy Renault LLP \\
\hline James Turner & Ontario Securities Commission \\
\hline Ula Ubani & BM0 Financial Group \\
\hline Neeti Varma & Ontario Securities Commission \\
\hline Ed Waitzer & Hennick Centre for Business and Law \\
\hline Alan Willis & Alan Willis \& Associates \\
\hline Daphne Wong & Ontario Securities Commission \\
\hline Bianca Wylie & Canadian CSR Centre for Excellence \\
\hline Mark Zekulin & Ministry of Finance \\
\hline
\end{tabular}




\section{APPENDIX E - CORPORATE SOCIAL PERFORMANCE: REPORTING ROUNDTABLE}

Sponsored by: Association of Chartered Certified Accountants
Monday, December 7, 2009

8:30 am-4:00 pm

Stikeman Elliott LLP 5300 Commerce Court West

199 Bay Street Toronto, Canada

AGENDA

8:30 - 8:45 Welcoming Remarks

Ed Waitzer,

Hennick Centre for Business and Law

8:45 - 9:15 Introductory Comments

Laurel Broten,

MPP Etobicoke-Lakeshore

9:15 - 10:15 Scope for "Regulation" of Social Reporting

- What are the legitimate needs of investors?

- Do the policy objectives discussed in the consultation paper merit regulation?

(Please see Section 2.2 of consultation paper.)

- Are there other legitimate reasons for regulating enhanced social reporting?

- Is the "materiality" standard sufficient to ensure adequate disclosure?

10:15-10:30 Break

10:30 - 12:00 Challenges Facing Issuers (and their service providers)

-What concerns exist for issuers in respect of social disclosure requirements?

- Should differently situated companies be treated differently? Should some companies be exempted from requirements altogether? If yes, based on what criteria?

- How can reliable, comparable reporting standards best be developed and promoted?

- What compliance/enforcement mechanisms are appropriate?

12:00 - 1:00 Working Lunch

-What can we learn from other jurisdictions?

1:00 - 1:15 Explain Break-0ut Sessions and Group Assignments

1:15-2:15 Break-Out Sessions

- Is regulatory reform warranted?

- If so, what options should be recommended?

- What other initiatives (e.g. research, voluntary standards) might be relevant and constructive?

2:15-2:30 Break

2:30 - 3:30 Report Back and Discussion

3:30 - 4:00 Closing Discussion - The Way Forward 


\section{APPENDIX F - DISSEMINATION STRATEGY AND COMMENTS RECEIVED}

The December 7th consultation paper was circulated to a broad audience in November-December 2009 in the following ways:

- Posted on the Hennick Centre website

- Posted on the Jantzi-Sustainalytics website

- Posted on the Social Science Research Network ("SSRN") and distributed via several SSRN abstracting journals

- Circulated to the listserv of the Social Investment Organization ("SIO")

- Sent to all participants of the September 18th consultation

- Sent to all invitees to the December 7th consultation

- Submitted to the UNPRI Engagement Clearinghouse

- Submitted for circulation to members of Financial Executives International

- Submitted for circulation to the Canadian Coalition for Good Governance

Comments were received from the following individuals:

- Jane Ambachtsheer, Mercer

- Andrea Baldwin, Canadian Business for Social Responsibility

- Ian Bragg, OPTrust

- Peter Chapman, SHARE

- Michelle de Cordova, Northwest \& Ethical Investments LP

- Julie Desjardins, CICA

- Aaron Dhir, Osgoode Hall Law School

- Eugene Ellmen, Social Investment Organization

- Celese Fletcher, Fletcher Consultancy

- Dermot Foley, Vancity Investment Management

- Steve Lydenberg, Domini Social Investments

- Jason Madden, JTM Law

- Jo-Anne Matear, Daphne Wong and Neeti Varma, 0sC Staff

- David Nitkin, EthicScan Canada

- Howard Sherman, GMI Ratings

- Alan Willis, CICA

- David Wood, Initiative for Responsible Investment 
